\title{
Effect of Abomasal Pectin Infusion on Digestion and Nitrogen Balance in Lactating Dairy Cows
}

\author{
T. F. Gressley and L. E. Armentano \\ Department of Dairy Science, University of Wisconsin, Madison 53706
}

\section{ABSTRACT}

Two experiments were conducted to test the hypothesis that increasing carbohydrate fermentation in the large intestine would increase intestinal conversion of blood urea $\mathrm{N}$ to microbial protein, thereby reducing urinary $\mathrm{N}$ output. In experiment 1,3 multiparous Holstein cows were used in an incomplete $4 \times 4$ Latin square with 14-d periods. Cows were fed the same basal diet and treatments were the abomasal infusion of $0,0.5$, or $1 \mathrm{~kg} / \mathrm{d}$ of citrus pectin, or the addition of $1 \mathrm{~kg} / \mathrm{d}$ of molasses to the basal diet. Experiment 2 used 6 cows in a double reversal design with four 21 -d periods. Cows were fed one basal diet and treatments were the abomasal infusion of either 0 or $1 \mathrm{~kg} / \mathrm{d}$ of pectin. In experiment 1 , pectin infusion linearly decreased basal ration intake from 25.0 to $23.2 \mathrm{~kg} / \mathrm{d}$. This was prevented in experiment 2 by restricted feeding, and basal ration intake was $22.2 \mathrm{~kg} / \mathrm{d}$. Abomasal pectin caused numeric decreases in total tract apparent digestibility of neutral detergent fiber and neutral detergent solubles in experiment 1 and significantly decreased starch digestibility in experiment 2 , suggesting that pectin may have reduced postruminal nutrient digestibility. Pectin infusion did not affect milk yield but decreased milk fat percentage from 3.69 to $3.53 \%$ in experiment 2 . Increasing abomasal pectin tended to decrease urinary $\mathrm{N}$ and increase fecal $\mathrm{N}$ in experiment 1 and these effects were significant in experiment 2 . For both experiments, urinary $\mathrm{N}$ decreased $26 \mathrm{~g} / \mathrm{d}$, approximately $10 \%$ of daily urine $\mathrm{N}$ output. Abomasal pectin did not affect fecal $\mathrm{pH}$ or DM content; however, in experiment 2 , pectin decreased fecal ammonia from 19.8 to $13.4 \mathrm{mmol} / \mathrm{kg}$ of $\mathrm{DM}$ and increased fecal purines from 13.8 to $15.8 \mathrm{mmol} /$ $\mathrm{kg}$ of DM. In both experiments, excretion of fecal purines was increased from $15 \mathrm{~g} / \mathrm{d}$ for $0 \mathrm{~kg} / \mathrm{d}$ pectin to 18 $\mathrm{g} / \mathrm{d}$ for $1 \mathrm{~kg} / \mathrm{d}$ pectin, although this increase was only significant in experiment 2 . These results suggest that manipulating dairy diets to increase postruminal fer-

Received January 11, 2005.

Accepted July 8, 2005.

Corresponding author: Louis E. Armentano; e-mail: learment@ wisc.edu. mentation may reduce urinary $\mathrm{N}$ and consequently manure ammonia losses. However, abomasal pectin tended to decrease both ruminal ammonia concentration and urinary purine derivative output in experiment 2 , suggesting that postruminal pectin fermentation may have compromised rumen microbial protein production.

(Key words: feces, nitrogen, pectin, urine)

Abbreviation key: 0 Pectin = abomasal infusion of saline only, 0.5 Pectin = abomasal infusion of $0.5 \mathrm{~kg} /$ $\mathrm{d}$ pectin in saline, $\mathbf{1}$ Pectin = abomasal infusion of 1.0 $\mathrm{kg} / \mathrm{d}$ pectin in saline, $\mathbf{1}$ Mol = abomasal infusion of saline only and $1.0 \mathrm{~kg} / \mathrm{d}$ of dried molasses was added to ration, $\mathbf{G a l A}=$ galacturonic acid, $\mathbf{M C P}=$ microbial crude protein, NDS = neutral detergent solubles, NDSF = neutral detergent-soluble fiber, TESC $=$ total $80 \%$ ethanol-soluble carbohydrates.

\section{INTRODUCTION}

Ammonia emissions from dairy manure reduce air quality and can be detrimental to human and animal health (James et al., 1999). Between 57 and $78 \%$ of urinary $\mathrm{N}$ is in the form of urea (de Boer et al., 2002). In the presence of feces, urinary urea $\mathrm{N}$ is rapidly converted into ammonia due to urease activity of fecal bacteria (Varel et al., 1999). However, fecal $\mathrm{N}$ is relatively stable during collection and storage (Varel et al., 1999).

On average, half of dairy cow manure $\mathrm{N}$ comes from feces and half comes from urine (Wright et al., 1998; Hristov and Ropp, 2003; Wattiaux and Karg, 2004); however, this ratio is affected by nutritional manipulation. Wright et al. (1998) fed cows diets containing 10.5, 17.0 , or $23.5 \% \mathrm{CP}$ at either 80 or $90 \%$ of ad libitum intake. Increasing CP from 10.5 to $23.5 \%$ increased fecal $\mathrm{N}$ by $30 \mathrm{~g} / \mathrm{d}$ and urinary $\mathrm{N}$ by $253 \mathrm{~g} / \mathrm{d}$. Consequently, urinary $\mathrm{N}$ as a percentage of excreted $\mathrm{N}$ increased from $31 \%$ on the low CP diet to $64 \%$ on the high CP diet. Although less dramatic than the effects of dietary CP, forage source and dietary NDF also appear to shift the relative excretion of urinary and fecal N. Wattiaux and Karg (2004) reported that cows excreted $56 \%$ of $\mathrm{N}$ in the urine when fed diets containing $41 \%$ alfalfa silage and $14 \%$ corn silage, and this was 
increased to $63 \%$ when diets contained $41 \%$ corn silage and $14 \%$ alfalfa silage. When Hristov and Ropp (2003) increased dietary NDF from 26.1 to $34.1 \%$, urinary $\mathrm{N}$ numerically decreased from 61.5 to $52.7 \%$ of total excreted N. Continued study of nutritional impacts on the pattern of $\mathrm{N}$ excretion may expose practical strategies to reduce ammonia emissions from manure and improve air quality.

Neutral detergent-soluble fibers (NDSF) are plant carbohydrates that are unavailable to mammalian digestive enzymes but are soluble in neutral detergent solution, thus making them available for metabolism by gut bacteria (Hall et al., 1999). Pectin is one class of NDSF and studies in monogastrics have shown that dietary pectin is completely degraded by resident intestinal bacteria (Cummings et al., 1979; Buchanan et al., 1994). Because pectin primarily provides energy, bacteria also require $\mathrm{N}$ for growth on pectin. Blood urea transfers freely between the postgastric digestive tract and body fluids (Hoover, 1978) and gut bacteria are capable of converting blood urea $\mathrm{N}$ into ammonia and subsequently microbial protein. Therefore, growth of intestinal microorganisms using energy supplied by pectin can result in a net conversion of blood urea $\mathrm{N}$ into fecal microbial $\mathrm{N}$, thereby reducing urinary $\mathrm{N}$. This was demonstrated when pectin was fed to rats (Brunsgaard et al., 1995) or infused into the sheep cecum (Mason et al., 1981). However, these experiments were done on animals fed near maintenance and the effects of postruminal pectin in lactating dairy cattle with relatively rapid rates of intake and passage has not been determined.

Two experiments were conducted to determine whether abomasal pectin infusions could decrease urinary $\mathrm{N}$ in lactating dairy cows. The magnitude of any response will help determine whether altering practical diets to increase postruminal microbial growth could be used as a tool to reduce ammonia volatilization from manure. A secondary objective of these experiments was to identify fecal characteristics that are altered by pectin infusion, with the intent of identifying a marker that could be used to quickly evaluate differences in postruminal fermentation of practical diets. Finally, it was assumed that effects of abomasal pectin would be due to stimulating growth of intestinal microbes. Increasing energy supply to ruminal microbes or to animal tissues as absorbed VFA should not produce the same effects. This assumption was tested in experiment 1 by comparing responses in cows receiving abomasal pectin to those of cows fed molasses.

\section{MATERIALS AND METHODS}

\section{Animals and Treatments}

Cows used in both experiments were rumen cannulated (10 cm center diameter; Bar Diamond, Parma,
ID) and housed in a stanchion barn with free access to water. Milking times were 0330 and $1530 \mathrm{~h}$, and milk weight was recorded at each milking. Cows were injected with bovine somatotropin $(500 \mathrm{mg}$ of Posilac; Monsanto Company, St. Louis, MO) every 2 wk. The Animal Care and Use Committee for the College of Agriculture and Life Sciences at the University of Wisconsin-Madison approved all animal procedures.

Experiment 1. Four multiparous, late-lactation (215 to 329 DIM at start of trial) Holstein cows were assigned to a $4 \times 4$ Latin square with 14 -d periods. All cows were fed the same basal diet (Table 1) containing alfalfa silage, corn silage, and steam-rolled corn. Steam-rolled corn was $0.39 \mathrm{~kg}$ of DM/L and 85\% DM (Lake Mills Feed and Grain, Lake Mills, WI). Rations were fed as 4 equal portions at $0900,1600,2100$, and $0400 \mathrm{~h}$ and refusals were removed at $0730 \mathrm{~h}$. The basal diet was fed at $120 \%$ of intake for $2 \mathrm{wk}$ immediately before the start of the experiment, and ad libitum DMI was estimated as the average DMI during the final $4 \mathrm{~d}$ of this pre-experimental period (mean of $26.4 \mathrm{~kg} / \mathrm{d}$ ). Each cow was offered the basal diet at $95 \%$ of its estimated ad libitum intake (mean of $25.1 \mathrm{~kg} / \mathrm{d}$ ) throughout the remainder of the experiment. Feeds were analyzed weekly for DM content and rations were adjusted accordingly.

Treatments were abomasal infusion of saline only $(\mathbf{0}$ Pectin), abomasal infusion of saline containing $0.5 \mathrm{~kg} /$ d pectin (0.5 Pectin), abomasal infusion of saline containing $1.0 \mathrm{~kg} / \mathrm{d}$ pectin (1 Pectin), or abomasal infusion of saline only, with $1 \mathrm{~kg} / \mathrm{d}$ dried molasses on soy hull carrier (Westway Feed Products, New Orleans, LA) added to the basal diet (1 Mol). Infusions began at 0900 $h$ on $d 6$ of each period and continued through d 14 (9 $\mathrm{d}$ of infusion). Weights of pectin and molasses were on an as-fed basis. Ingredient composition of the basal ration and nutrient contents of the basal ration, pectin, and molasses are listed in Table 1.

Studies using lactating cows with duodenal and ileal cannulas reported treatment means for large intestinal digestion ranging from 0.4 to $1.0 \mathrm{~kg} / \mathrm{d}$ of $\mathrm{OM}$ (Younker et al., 1998), from 0.8 to $1.4 \mathrm{~kg} / \mathrm{d}$ of OM (Callison et al., 2001), and from 0.8 to $3.5 \mathrm{~kg} / \mathrm{d}$ of DM (Knowlton et al., 1998). Therefore, for each of these studies, the greatest differences in $\mathrm{OM}$ or DM digestion in the large intestine between the treatment means were $0.6,0.6$, and $2.7 \mathrm{~kg} /$ $\mathrm{d}$, respectively. The 1 Pectin treatment was predicted to increase DM digestion in the large intestine by 1.0 $\mathrm{kg} / \mathrm{d}$ compared with the 0 Pectin treatment. This amount was chosen to increase large intestinal DM digestion by an amount that could be obtained by other, more practical, dietary manipulations. To determine if 
Table 1. Ingredient composition of the basal diets and nutrient contents as analyzed in the basal diets, pectin, and molasses.

\begin{tabular}{|c|c|c|c|c|c|}
\hline & \multicolumn{3}{|c|}{ Experiment 1} & \multicolumn{2}{|c|}{ Experiment 2} \\
\hline & Basal diet & Pectin $^{1}$ & Molasses $^{2}$ & Basal diet & Pectin $^{1}$ \\
\hline \multicolumn{6}{|l|}{ Ingredient } \\
\hline Alfalfa silage & 31.2 & & & 20.0 & \\
\hline Corn silage & 26.3 & & & 37.0 & \\
\hline Steam-rolled corn & 22.5 & & & 21.3 & \\
\hline Soybean meal & 8.1 & & & 9.8 & \\
\hline Cottonseed & 6.1 & & & 6.1 & \\
\hline Meat and bone meal & 3.0 & & & 3.0 & \\
\hline Blood meal & 1.0 & & & 1.0 & \\
\hline Sodium bicarbonate & 0.8 & & & 0.8 & \\
\hline Trace mineral salt ${ }^{3}$ & 0.7 & & & 0.7 & \\
\hline Vitamin $\operatorname{mix}^{4}$ & 0.3 & & & 0.3 & \\
\hline \multicolumn{6}{|l|}{ Nutrient } \\
\hline NDF & 27.4 & 0.0 & 22.1 & 30.2 & 0.0 \\
\hline NDF from forage & 21.4 & 0.0 & 0.0 & 22.0 & 0.0 \\
\hline $\mathrm{ADF}$ & 18.5 & 0.0 & 16.8 & 17.3 & 0.0 \\
\hline Starch & 28.2 & 1.3 & 1.3 & 25.9 & 0.1 \\
\hline $\mathrm{FA}^{5}$ & 2.8 & 0.1 & 0.7 & 3.5 & 0.4 \\
\hline $\mathrm{CP}$ & 16.6 & 3.9 & 7.1 & 17.3 & 2.4 \\
\hline $\mathrm{RDP}^{6}$ & 10.4 & - & 7.1 & 10.9 & - \\
\hline RUP $^{6}$ & 6.2 & - & 0.0 & 6.4 & - \\
\hline $\mathrm{NFC}^{7}$ & 42.9 & 93.0 & 58.3 & 40.4 & 93.8 \\
\hline $\mathrm{NDSF}^{8}$ & 10.1 & 80.3 & 11.7 & 10.0 & 72.4 \\
\hline TESC $^{9}$ & 2.9 & 17.3 & 41.9 & 3.5 & 24.9 \\
\hline Ash & 9.3 & 2.0 & 10.8 & 7.7 & 2.4 \\
\hline DM, \% & 53.7 & 96.8 & 97.7 & 49.0 & 97.5 \\
\hline
\end{tabular}

\footnotetext{
${ }^{1}$ Pectin (HM Slow-Set Pectin; TIC Gums, Belcamp, MD) extracted with $80 \%$ ethanol. Nutrient composition reported as analyzed.

${ }^{2}$ Molasses on a soyhull carrier (Westway Feed Products, New Orleans, LA). Nutrient composition reported as analyzed.

${ }^{3}$ Contained $0.55 \% \mathrm{Mn}, 0.55 \% \mathrm{Zn}, 0.35 \% \mathrm{Fe}, 0.14 \% \mathrm{Cu}, 0.008 \% \mathrm{I}, 0.006 \%$ Se, and $0.002 \% \mathrm{Co}$.

${ }^{4}$ Contained $3304 \mathrm{IU} / \mathrm{g}$ of DM of vitamin A, $1101 \mathrm{IU} / \mathrm{g}$ of DM of vitamin D, and $11 \mathrm{IU} / \mathrm{g}$ of DM of vitamin E.

${ }^{5} \mathrm{FA}=$ Fatty acids. Represented the sum of $\mathrm{C}_{12}$ to $\mathrm{C}_{18}$.

${ }^{6} \mathrm{RDP}$ and RUP calculated from NRC, 2001.

${ }^{7} \mathrm{NFC}=100-(\mathrm{FA}+1+\mathrm{NDF}+\mathrm{CP}+\mathrm{ash})$

${ }^{8} \mathrm{NDSF}=$ Neutral detergent-soluble fiber (Hall et al., 1999).

${ }^{9} \mathrm{TESC}=$ Total $80 \%$ ethanol-soluble carbohydrate content measured using sucrose as the standard (Hall et al., 1999).
}

the effects of the 1 Pectin treatment were due to increasing energy for postruminal microbial growth specifically and not to increasing VFA supply to animal tissues or to the dilution of dietary protein, the $1 \mathrm{Mol}$ treatment was included as an isoenergetic control. Molasses was chosen as the substrate for the isoenergetic control because preliminary evidence suggested that feeding pectin would reduce palatability of the basal diet.

Experiment 2. Interpretation of data from experiment 1 was difficult due to differences in basal ration intake among treatments. In addition, fecal DM and $\mathrm{N}$ flow may have been overestimated by the marker technique used in experiment 1 . Experiment 2 was conducted to more precisely examine the treatment effects of 0 Pectin and 1 Pectin. Six multiparous, mid- to latelactation (125 to 250 DIM at start of trial) Holstein cows were fed the same basal ration for $28 \mathrm{~d}$ before the start of the experiment. Following this pre-experimental period, cows were assigned to a replicated double reversal design with four 21-d periods. According to this design, 3 cows received treatments in the order 0 Pectin, 1 Pectin, 0 Pectin, 1 Pectin over 4 periods, whereas the treatment order for the remaining 3 cows was 1 Pectin, 0 Pectin, 1 Pectin, 0 Pectin. Diets were similar to those fed in experiment 1 (Table 1) except that steam-rolled corn was less aggressively processed. Corn was $0.55 \mathrm{~kg}$ of DM/L and 85\% DM (Lake Mills Feed and Grain) compared with $0.39 \mathrm{~kg}$ of DM/L in experiment 1 . Rations were fed as 4 equal portions at $0700,1200,1630$, and $2300 \mathrm{~h}$ and refusals were removed at $0630 \mathrm{~h}$. Treatments were identical to the 0 Pectin and 1 Pectin treatments in experiment 1 except 
that infusions began at $0700 \mathrm{~h}$ on $\mathrm{d} 11$ of each period and continued through $\mathrm{d} 21$ ( $11 \mathrm{~d}$ of infusion).

Due to the effect of pectin on basal ration DMI in experiment 1 , the 4 -wk pre-experimental period was used to determine voluntary intake on the 1 Pectin treatment. For the first $3 \mathrm{wk}$ of this period, the basal ration was fed at $110 \%$ of intake and ad libitum intake was estimated for each cow as DMI from d 15 to 21 $($ mean $=26.7 \mathrm{~kg} / \mathrm{d})$. For d 22 through 28 , each cow was fed at $95 \%$ of its estimated ad libitum intake (mean = $25.4 \mathrm{~kg} / \mathrm{d}$ ) and received the 1 Pectin infusion. All cows consumed all of the feed offered; therefore, cows continued to be fed the same amount ( mean $=25.4 \mathrm{~kg} / \mathrm{d}$ ) into period 1. However, during period 1 before the start of the infusions, DMI immediately and unexpectedly dropped below the amount offered for 4 of the 6 cows ( 2 cows from each treatment sequence). To ensure complete consumption of the basal ration, feed offered to all cows was reduced further. Average intake for each cow from d 1 to 10 of period 1 was calculated (mean = $23.4 \mathrm{~kg} / \mathrm{d})$. Feed offered from d 11 of period 1 through the remainder of the experiment $($ mean $=22.3 \mathrm{~kg} / \mathrm{d}$ ) was $95 \%$ of that consumed during $d 1$ to 10 of period 1 .

Infusions. High-methoxyl slow-set pectin (TIC Gums, Belcamp, MD) was infused. This pectin is derived from citrus peels and, according to the manufacturer, 55 to $60 \%$ of the available carboxyl groups on the galacturonic acid (GalA) backbone are methyl esters. The manufacturer adds glucose to the pectin as a standardizing agent. Before infusions, glucose was removed by shaking each kilogram of pectin (Orbital Shaker model 57018-754; VWR Scientific Products, West Chester, PA) in $4 \mathrm{~L}$ of $80 \%$ ethanol for $4 \mathrm{~h}$, collecting solids by filtration (Whatman 541 ), and drying at $60^{\circ} \mathrm{C}$. This ethanol-extracted pectin contained 77.9 and $77.1 \%$ of the original pectin DM for experiments 1 and 2, respectively. Free glucose content was reduced from 36.5 to $13.7 \%$ in experiment 1 and from 36.6 to $20.0 \%$ in experiment 2.

Abomasal infusions were saline $(9 \mathrm{~g}$ of $\mathrm{NaCl} / \mathrm{L}$ of distilled water) with or without dispersed pectin. Infusion rates were $20 \mathrm{~L} / \mathrm{d}$ in experiment 1 and $30 \mathrm{~L} / \mathrm{d}$ in experiment 2 . Infusions were continuous throughout the day except for about $1.5 \mathrm{~h}$ during milking. Plastisol (P-6003; QCM Company, Kent, WA) discs (12 cm in diameter and $9 \mathrm{~mm}$ in height) were used to anchor the infusion tubing in the abomasum, and placement of infusion lines in the abomasum was monitored daily. For pectin infusions, half of each day's infusion $(10 \mathrm{~L}$ for experiment 1 and $15 \mathrm{~L}$ for experiment 2) was prepared at a time. Water and $\mathrm{NaCl}$ were added to $20-\mathrm{L}$ plastic buckets. The buckets were then put under an electric mixer (Talboys Laboratory Stirrer, model \#107, Troemner LLC, Thorofare, NJ) and pectin was slowly added while the mixer was on. Mixing continued for 1 $\mathrm{h}$ to allow for complete dispersion of pectin into saline. Variable-speed peristaltic pumps (Mec-o-matic VSP-20; W.W.Grainger, Inc., Lincolnshire, IL) were used to deliver the infusion mixtures through PVC tubing $(0.63$ $\mathrm{cm}$ ID) at a rate of $20 \pm 0.5 \mathrm{~L} / \mathrm{d}$ over $24 \mathrm{~h}$ for experiment 1 and $30 \pm 0.5 \mathrm{~L} / \mathrm{d}$ over $24 \mathrm{~h}$ for experiment 2 . An electric heating pad held in place by fiberglass insulation was placed around each bucket delivering pectin. Heat was applied when daily temperatures were below $0^{\circ} \mathrm{C}$ to prevent clogging of the infusion lines.

In experiment 1 , failure of the infusion device occurred for one cow and a Plastisol disc was lost in its abomasum. Intake was subsequently reduced and the cow was removed from the experiment, resulting in an incomplete Latin square.

\section{Sampling}

Experiment 1. Feed samples were taken weekly, dried for $48 \mathrm{~h}$ in a $60^{\circ} \mathrm{C}$ forced-air oven, and composited by period. Samples of any refusals were taken during the last $4 \mathrm{~d}$ of each period, and intake was corrected for refusal DM content. Throughout the experiment, a bolus containing lanthanum oxide $\left(\mathrm{La}_{2} \mathrm{O}_{3}\right)$ dissolved in $\mathrm{HCl}$ and carried on soy hulls was inserted into the rumen twice daily at 0900 and $2100 \mathrm{~h}$, supplying a total of $0.90 \mathrm{~g}$ of La/d. Lanthanum was dosed to the animals to predict fecal output and diet digestibility.

Fecal, urine, and rumen samples were taken 12 times over the last $4 \mathrm{~d}$ of each period. For each period, sampling began at 1800 and $0200 \mathrm{~h}$ on d 11, 1000, 1400, 2200 , and $0600 \mathrm{~h}$ on d 12,1800 and $0200 \mathrm{~h}$ on d 13, and 1000, 1400, 2200, and 0600 on d 14, and each sampling took approximately $2 \mathrm{~h}$. For statistical analyses, sampling times were listed as $1 \mathrm{~h}$ after the start of each sampling period.

Fecal grab samples were taken and a portion (approximately $100 \mathrm{~g}$ ) was dried for $48 \mathrm{~h}$ at $60^{\circ} \mathrm{C}$ and composited by cow within period for later component analysis. Composites of dried feces contained an equal amount of fecal DM from each sampling point. A portion of fresh feces was frozen at $-20^{\circ} \mathrm{C}$ for later $\mathrm{N}$ analysis and the rest was used for determination of $\mathrm{pH}, \mathrm{NH}_{3}$, and VFA. Approximately $25 \mathrm{~g}$ of fresh feces was weighed into each of 3 specimen cups. To the first cup, an amount of distilled water equal to $50 \%$ of the feces wet weight was added. To the second and third cups, $10 \mathrm{~mL}$ of distilled water plus $0.43 \mathrm{~mL}$ of $50 \% \mathrm{H}_{2} \mathrm{SO}_{4}$ and $10 \mathrm{~mL}$ of distilled water plus $0.43 \mathrm{~mL}$ of $50 \%$ TCA were added, respectively. Each cup was shaken vigorously for $20 \mathrm{~s}$ and liquids were squeezed through one layer of cheesecloth. Liquids from the first cup were measured for $\mathrm{pH}$, and liquids from the second and third cups were frozen at 
$-20^{\circ} \mathrm{C}$ for later analysis of VFA and $\mathrm{NH}_{3}$, respectively. Urine spot samples were taken, acidified with $50 \%$ $\mathrm{H}_{2} \mathrm{SO}_{4}\left(0.01 \mathrm{~mL} / \mathrm{mL}\right.$ of urine), and frozen at $-20^{\circ} \mathrm{C}$. Before analysis, urine samples were composited by cow within period so that each time point represented an equal volume in the composite.

Ruminal fluid samples from 5 consistent locations within the rumen were taken using a stainless steel filter probe. The probe was $1 \mathrm{~m}$ long and $6 \mathrm{~mm}$ in diameter. A cylinder $5 \mathrm{~cm}$ in length, $2 \mathrm{~cm}$ in diameter, and covered with $1 \mathrm{~mm}$ diameter holes capped the sampling end. The other end was connected to a $60-\mathrm{mL}$ syringe used to collect the samples. Rumen fluid $\mathrm{pH}$ was measured (Twin pH-meter model B-213, Spectrum Technologies Inc., Plainfield, IL). One milliliter of rumen fluid was added to each of two 1.5-mL microfuge tubes containing $0.02 \mathrm{~mL}$ of $50 \% \mathrm{H}_{2} \mathrm{SO}_{4}$. Tubes were frozen at $-20^{\circ} \mathrm{C}$ for later VFA analysis. The same process was used to preserve rumen fluid for $\mathrm{NH}_{3}$ analysis except that the tubes contained $0.02 \mathrm{~mL}$ of $50 \%$ TCA as the preservative.

Cows were weighed just before the 0900 -h feeding on the final $2 \mathrm{~d}$ of each period. Duplicate milk samples from both a.m. and p.m. milkings were taken during the final $3 \mathrm{~d}$ of each period. One set of duplicate samples was analyzed for fat, true protein, and MUN by infrared analysis (Foss 605 for fat and protein and Foss 4000 for MUN; AgSource Milk Analysis Laboratory, Menomonie, WI). The second set of samples was refrigerated until the end of each sampling period, composited by cow according to milk production, and frozen at $-20^{\circ} \mathrm{C}$ until $\mathrm{N}$ analysis.

Experiment 2. Feed samples were taken weekly, composited by period, and frozen at $-20^{\circ} \mathrm{C}$ until freezedrying (model 77540; Labconco, Kansas City, MO). Fecal grab samples were taken 8 times during the last 3 $\mathrm{d}$ of each period. The first sampling was at $1200 \mathrm{~h}$ on d 19 and subsequent samplings were taken every $9 \mathrm{~h}$ thereafter. Samples were processed for $\mathrm{DM}, \mathrm{pH}, \mathrm{NH}_{3}$, and VFA, as described for experiment 1 , and then discarded.

Total collections of feces and urine were performed on d 19 to 21 of each period. Feces were collected in pans fitted over the gutters. Urine was collected using indwelling catheters (75-cc Bardex Lubricath; C. R. Bard, Inc., Covington, GA) that drained into 4 vessels per d, each containing $0.3 \mathrm{~L}$ of $50 \% \mathrm{H}_{2} \mathrm{SO}_{4}$. Feces weight and urine volumes were recorded twice daily and feces and urine samples were taken twice daily. A concrete mixing paddle attached to a heavy-duty drill was used to mix feces for $2 \mathrm{~min}$ before sampling. Urine containers were shaken to mix. Fecal and urine samples were stored at $-20^{\circ} \mathrm{C}$. Fecal samples were composited by cow and period according to wet daily outputs and were freeze dried. For analyses, urine samples were composited by cow and period by volume according to daily production.

Rumen fluid samples were taken on d 18 of each period at 0800, 1200, 1600, 2000, 2400, and $0400 \mathrm{~h}$. Rumen $\mathrm{pH}$ was measured and samples were aliquoted for VFA and $\mathrm{NH}_{3}$ as described for experiment 1 . In sacco rumen measurements were also performed on $d$ 18. Quadruplicate Dacron polyester bags $(9 \times 15 \mathrm{~cm}$, $52 \pm 5 \mu \mathrm{m}$ pore size) were incubated in each cow for $12 \mathrm{~h}$ to determine DM and NDF disappearance. Bags containing $5 \mathrm{~g}$ (DM basis) of soy hulls were soaked in warm water for 5 min before incubation, placed in a nylon laundry bag, and inserted in the ventral sac of the rumen. After incubation, bags were rinsed in cold water and washed in a commercial washing machine for 2 cycles of 15 min each. Disappearance of DM and $\mathrm{NDF}$ after $12 \mathrm{~h}$ was corrected for DM and NDF losses in bags that were soaked and laundered without ruminal incubation.

Cows were weighed at $0800 \mathrm{~h}$ on $\mathrm{d} 18$ and 21. Cows were milked in their stalls using a portable milking machine during the total urine and fecal collection, $d$ 19 to 21 . Duplicate milk samples were taken at each milking from d 19 to 21 for infrared and $\mathrm{N}$ analysis as described for experiment 1 except that Foss 6000 was used to determine MUN. One set of milk samples was composited by cow and period based on daily milk weights and frozen at $-20^{\circ} \mathrm{C}$ until $\mathrm{N}$ analysis.

\section{Sample Analyses}

Oven-dried (experiment 1) and freeze-dried (experiment 2) feed and fecal samples were ground through a 1-mm screen (Wiley mill, Arthur H. Thomas, Philadelphia, PA). Ground feed and fecal samples were analyzed for DM, OM, CP, NDF, ADF, NDSF, and total ethanol soluble carbohydrates (TESC). Feed samples were additionally analyzed for fatty acids, and fecal samples from experiment 1 were analyzed for La. Galacturonic acid was determined on pectin and fecal samples. Milk was analyzed for $\mathrm{CP}$ and urine samples were analyzed for CP, allantoin, uric acid, and creatinine. Dry matter and NDF were determined on in sacco samples from experiment 2. Rumen samples and spot fecal samples were analyzed for VFA and $\mathrm{NH}_{3}$. To prevent clumping, pectin samples were wet with $80 \%$ ethanol before NDSF, TESC, and GalA procedures.

Dry matter was determined by drying overnight in a $100^{\circ} \mathrm{C}$ forced-air oven. Organic matter was determined by oven drying at $550^{\circ} \mathrm{C}$ for $12 \mathrm{~h}$. Crude protein was analyzed by microKjeldahl for feed, dried fecal, and urine samples and by macro-Kjeldahl for milk samples (AOAC, 1990). Neutral detergent fiber was determined 
using $\alpha$-amylase (A3306; Sigma Chemical Co., St. Louis, MO) without sodium sulfite and corrected for ash concentration according to Van Soest et al. (1991), adapted for Ankom ${ }^{200}$ Fiber Analyzer (Ankom Technology, Fairport, NY). Acid detergent fiber was determined using the method of Goering and Van Soest (1970) adapted for the Ankom ${ }^{200}$. Fatty acids were analyzed according to Sukhija and Palmquist (1988) and represented the sum of $\mathrm{C}_{12}$ to $\mathrm{C}_{18}$.

For experiment 1, CP in frozen fecal samples was determined by macro-Kjeldahl. Samples from individual time points were thawed and composited by cow and period so that each time point contained an equal wet weight in the composite sample. These results were compared with $\mathrm{N}$ determined by microKjeldahl on dried, ground fecal samples, and $\mathrm{N}$ loss due to drying was predicted.

Neutral detergent-soluble fiber and TESC were determined based on the methods of Hall et al. (1999) with the following clarifications. Sucrose was used as the standard for determination of TESC. Neutral detergent residue and neutral detergent residue $\mathrm{CP}$ procedures were adapted for the Ankom ${ }^{200}$. For experiment 1 , glucose content of hydrolyzed starch samples was determined using a colorimetric glucose oxidase assay (No. 510-A; Sigma Chemical Co.). Free glucose was determined using the procedure for starch analysis but without adding amylase or amyloglucosidase.

Concentration of La in fecal samples was determined by direct current plasma emission spectroscopy (Spectra Metrics, Inc., subsidiary of Beckman Instruments, Inc., Andover, MA) according to Combs and Satter (1992). For experiment 1, fecal outputs were calculated based on fecal La as:

\section{Fecal DM $(\mathrm{kg} / \mathrm{d})=$}

La dosed (mg/d) / La in feces (mg/kg of fecal DM).

In experiment 2 , fecal output was measured directly. For both experiments, digestibility calculations included infused pectin as a component of intake.

Galacturonic acid was analyzed in triplicate $(0.1 \mathrm{~g}$ each). Samples were suspended in $20 \mathrm{~mL}$ of $0.5 \%$ ammonium oxalate and were placed in a shaking 70 to $80^{\circ} \mathrm{C}$ water bath for $1 \mathrm{~h}$ (Hatfield and Weimer, 1995). Following incubation, extracts were filtered through glass fiber filter paper (Whatman GF/A) and brought to 100 $\mathrm{mL}$ with $0.5 \%$ ammonium oxalate. The extract was analyzed on the same day for GalA using the colorimetric procedure described by Van Soest et al. (1991).

Fecal and rumen fluid samples were analyzed for VFA concentrations by GLC (Perkin Elmer Autosystem, Norwalk, CT) and for $\mathrm{NH}_{3}$ as described by Bal et al. (2000). Fecal purines were analyzed according to Pereira and Armentano (2000) although an equimolar ratio of guanine and adenine was used for the standard.

Urine samples were diluted $1 / 50$ with distilled water before determination of creatinine, allantoin, and uric acid. Creatinine was determined using a colorimetric assay [No. 555-A (Sigma Chemical Co.) for experiment 1 and Teco no. C515-480 (Teco Diagnostics, Anaheim, CA) for experiment 2]. In experiment 2 , average daily creatinine output was determined to be $28.1 \mathrm{mg} / \mathrm{kg}$ of BW. In experiment 1 , daily urine output (L/d) was estimated from urinary creatinine and BW as: $28.1[\mathrm{mg} /$ $\left.\mathrm{kg}^{-1}\right] \times \mathrm{BW}[\mathrm{kg}] \times(1 /$ urinary creatinine $[\mathrm{mg} / \mathrm{L}])$. Concentration of allantoin was determined by the methods of Chen and Gomes (1992) except that $1 M \mathrm{HCl}$ was used instead of $0.5 \mathrm{M} \mathrm{HCl}$ to maintain a $\mathrm{pH}$ below 3 . Uric acid concentration was determined colorimetrically [Sigma no. 685 (Sigma Chemical Co.) for experiment 1, and Teco no. U580-240 (Teco Diagnostics, Anaheim, CA) for experiment 2].

\section{Statistical Analyses}

Data were analyzed using the Mixed procedure of SAS (SAS Institute, 1999).

Experiment 1. Most variables had only one value per cow per period and were analyzed using the model:

$$
Y=\mu+T_{i}+P_{j}+C_{k}+e_{i j k}
$$

where $\mu=$ overall mean; $T_{i}=$ fixed effect of treatment; $P_{j}=$ fixed effect of period; $C_{k}=$ random effect of cow; and $\mathrm{e}_{\mathrm{ijk}}=$ random residual error.

Repeated measurements of rumen and fecal VFA, $\mathrm{NH}_{3}$, and $\mathrm{pH}$, and of fecal DM were analyzed as:

$$
\begin{aligned}
\mathrm{Y}= & \mu+\mathrm{T}_{\mathrm{i}}+\mathrm{P}_{\mathrm{j}}+\mathrm{C}_{\mathrm{k}}+\mathrm{T}_{\mathrm{i}} \times \mathrm{P}_{\mathrm{j}} \times \mathrm{C}_{\mathrm{k}}+\mathrm{H}_{\mathrm{l}}+\mathrm{D}_{\mathrm{m}} \\
& +\mathrm{T}_{\mathrm{i}} \times \mathrm{H}_{\mathrm{l}}+\mathrm{P}_{\mathrm{j}} \times \mathrm{H}_{\mathrm{l}}+\mathrm{H}_{\mathrm{l}} \times \mathrm{D}_{\mathrm{m}}+\mathrm{e}_{\mathrm{ijkl} \mathrm{m}},
\end{aligned}
$$

where $\mu=$ overall mean; $T_{i}=$ fixed effect of treatment; $\mathrm{P}_{\mathrm{j}}=$ fixed effect of period; $\mathrm{C}_{\mathrm{k}}=$ random effect of cow; $\mathrm{H}_{\mathrm{l}}=$ fixed effect of hour after initial $0900 \mathrm{~h}$ feeding; $\mathrm{D}_{\mathrm{m}}=$ identifier of samples taken during the first $2(\mathrm{D}=$ 1) or second $2(\mathrm{D}=2)$ days of each sampling period; and $\mathrm{e}_{\mathrm{ijklm}}=$ random residual error. All interactions were considered fixed effects except $\mathrm{T}_{\mathrm{i}} \times \mathrm{P}_{\mathrm{j}} \times \mathrm{C}_{\mathrm{k}}$, which was considered random. The spatial power covariate structure was used and the subject was $\mathrm{T}_{\mathrm{i}} \times \mathrm{P}_{\mathrm{j}} \times \mathrm{C}_{\mathrm{k}}$.

For all models, 3 preplanned contrasts were tested. Two contrasts tested for the linear and quadratic effects of increasing levels of pectin infusion $(0,0.5$, and 1 Pectin). The final contrast tested the effect of site of digestion of the added substrate (1 Pectin vs. $1 \mathrm{Mol}$ ). 
Table 2. Least squares mean nutrient intakes for each treatment including nutrients from pectin and molasses ( $\mathrm{n}=3$ for experiment 1 and $\mathrm{n}=6$ for experiment 2 ).

\begin{tabular}{|c|c|c|c|c|c|c|}
\hline & \multicolumn{4}{|c|}{ Experiment $1^{1}$} & \multicolumn{2}{|c|}{ Experiment $2^{1}$} \\
\hline & 0 Pectin & 0.5 Pectin & 1 Pectin & $1 \mathrm{Mol}$ & 0 Pectin & 1 Pectin \\
\hline Nutrient & & & Intake $+\mathrm{i}$ & $\mathrm{d}, \mathrm{kg} / \mathrm{d}$ & 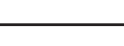 & 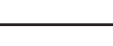 \\
\hline $\mathrm{OM}$ & 22.6 & 22.5 & 22.0 & 22.6 & 20.5 & 21.4 \\
\hline $\mathrm{NDF}$ & 6.79 & 6.70 & 6.38 & 6.74 & 6.70 & 6.68 \\
\hline Forage NDF & 5.29 & 5.25 & 4.98 & 5.09 & 4.87 & 4.89 \\
\hline $\mathrm{ADF}$ & 4.62 & 4.50 & 4.30 & 4.61 & 3.86 & 3.84 \\
\hline Starch & 7.04 & 6.85 & 6.53 & 6.82 & 5.76 & 5.76 \\
\hline Fatty acids ${ }^{2}$ & 0.69 & 0.67 & 0.65 & 0.68 & 0.81 & 0.81 \\
\hline $\mathrm{CP}$ & 4.16 & 4.02 & 3.89 & 4.04 & 3.84 & 3.83 \\
\hline $\mathrm{NFC}^{3}$ & 10.7 & 10.8 & 10.8 & 10.9 & 8.93 & 8.93 \\
\hline $\mathrm{NDSF}^{4}$ & 2.53 & 2.82 & 3.14 & 2.55 & 2.23 & 2.92 \\
\hline TESC $^{5}$ & 0.72 & 0.78 & 0.84 & 1.09 & 0.77 & 0.78 \\
\hline Ash & 2.33 & 2.27 & 2.19 & 2.34 & 1.71 & 1.73 \\
\hline
\end{tabular}

${ }^{1}$ Treatments: 0 Pectin = abomasal infusion of saline only; 0.5 Pectin = abomasal infusion of $0.5 \mathrm{~kg} / \mathrm{d}$ pectin in saline; 1 Pectin = abomasal infusion of $1.0 \mathrm{~kg} / \mathrm{d}$ pectin in saline; $1 \mathrm{Mol}=$ abomasal infusion of saline only and $1.0 \mathrm{~kg} / \mathrm{d}$ dried molasses was added to ration.

${ }^{2}$ Represented the sum of $\mathrm{C}_{12}$ to $\mathrm{C}_{18}$.

${ }^{3} \mathrm{NFC}=100-(\mathrm{FA}+1+\mathrm{NDF}+\mathrm{CP}+\mathrm{ash})$.

${ }^{4} \mathrm{NDSF}=$ Neutral detergent-soluble fiber (Hall et al., 1999).

${ }^{5} \mathrm{TESC}=$ Total $80 \%$ ethanol-soluble carbohydrate content measured using sucrose as the standard (Hall et al., 1999).

Fermentation of added molasses and pectin were assumed to occur in the rumen and intestines, respectively. Significance was declared at $P \leq 0.05$. Due to the relative low power of this experiment, a trend was declared at $P \leq 0.15$.

Experiment 2. For variables with only one value per cow per period, the model used was:

$$
\mathrm{Y}=\mu+\mathrm{T}_{\mathrm{i}}+\mathrm{P}_{\mathrm{j}}+\mathrm{S}_{\mathrm{k}}+\mathrm{C}_{\mathrm{l}}+\mathrm{e}_{\mathrm{ijk} \mathrm{k}}
$$

where $\mu$ = overall mean; $T_{i}=$ fixed effect of treatment; $\mathrm{P}_{\mathrm{j}}=$ fixed effect of period; $\mathrm{S}_{\mathrm{k}}=$ fixed effect of treatment sequence; $\mathrm{C}_{\mathrm{l}}=$ random effect of cow; and $\mathrm{e}_{\mathrm{ijk} \mathrm{l}}=$ random residual error.

Repeated measurements of rumen and fecal VFA, $\mathrm{NH}_{3}$, and $\mathrm{pH}$, and of fecal DM were analyzed as:

$$
\begin{aligned}
\mathrm{Y}=\mu+\mathrm{T}_{\mathrm{i}}+ & \mathrm{P}_{\mathrm{j}}+\mathrm{S}_{\mathrm{k}}+\mathrm{C}_{\mathrm{l}}+\mathrm{T}_{\mathrm{i}} \times \mathrm{P}_{\mathrm{j}} \times \mathrm{C}_{\mathrm{l}}+\mathrm{H}_{\mathrm{m}} \\
& +\mathrm{T}_{\mathrm{i}} \times \mathrm{H}_{\mathrm{m}}+\mathrm{e}_{\mathrm{ijklm}},
\end{aligned}
$$

where $\mu$ = overall mean; $T_{i}=$ fixed effect of treatment; $P_{j}=$ fixed effect of period; $S_{k}=$ fixed effect of treatment sequence; $\mathrm{C}_{\mathrm{l}}=$ random effect of cow; $\mathrm{H}_{\mathrm{m}}=$ fixed effect of hour after initial $0700 \mathrm{~h}$ feeding; and $\mathrm{e}_{\mathrm{ijklm}}=$ random residual error. $\mathrm{T}_{\mathrm{i}} \times \mathrm{H}_{\mathrm{m}}$ was considered a fixed effect, $\mathrm{T}_{\mathrm{i}}$ $\times \mathrm{P}_{\mathrm{j}} \times \mathrm{C}_{1}$ was considered random, and the subject was $\mathrm{T}_{\mathrm{i}} \times \mathrm{P}_{\mathrm{j}} \times \mathrm{C}_{\mathrm{l}}$. The covariance structures used were autoregressive and heterogeneous autoregressive for fecal and rumen measures, respectively. For both models, significance was declared at $P \leq 0.05$ and a trend was declared at $P \leq 0.10$.

\section{RESULTS AND DISCUSSION}

\section{Intake and Digestion}

Nutrient intakes including pectin and molasses are listed in Table 2. The basal diets were formulated to meet or exceed energy and nutrient requirements at the restricted feeding levels (NRC, 2001). In experiment 1 , CP content measured in the grain mix $(20.6 \%$ CP) was lower than expected from pre-experimental feed analysis (23.0\% CP). The NRC (2001) model was used to predict RUP supply after assuming that the difference in grain mix CP percentage was due to a $10 \%$ drop in CP content of all grain mix ingredients. Based on actual production and intake data, NRC (2001) predicted RUP requirements were 1712, 1529, 1592, and $1375 \mathrm{~g} / \mathrm{d}$, and supplies of RUP were 1545, 1497, 1416, and $1497 \mathrm{~g} / \mathrm{d}$ for treatments 0 Pectin, 0.5 Pectin, 1 Pectin, and $1 \mathrm{Mol}$, respectively. Balance of RUP was therefore $-167,-32,-176$, and $+122 \mathrm{~g} / \mathrm{d}$ for treatments 0 Pectin, 0.5 Pectin, 1 Pectin, and $1 \mathrm{Mol}$, respectively. No other deficiencies were predicted.

Although the basal diet offered was restricted to $95 \%$ of predicted ad libitum intake in experiment 1 , basal ration intake was affected by treatment (Table 3). Pectin infusion caused a linear reduction in basal diet DMI $(P=0.04)$. Consequently, total DM inputs including pectin were not different between 0 Pectin and 1 Pectin. The reduction in basal ration intake suggests that postruminal pectin itself or intestinal pectin degradation products reduced intake. One possibility is that the VFA energy supplied by the pectin infusion caused the 
Table 3. Experiment 1: Effect of abomasal pectin infusion or ruminal molasses on intake and digestion $(\mathrm{n}=3)$.

\begin{tabular}{|c|c|c|c|c|c|c|c|c|}
\hline & \multicolumn{3}{|c|}{ Pectin $^{1}$} & \multirow{2}{*}{$\frac{\mathrm{Mol}^{1}}{1}$} & \multirow[b]{2}{*}{$\mathrm{SED}^{3}$} & \multicolumn{3}{|c|}{ Contrasts $^{2}$} \\
\hline & 0 & 0.5 & 1 & & & Linear & Quadratic & Site \\
\hline & \multicolumn{4}{|c|}{$\longrightarrow \mathrm{kg} / \mathrm{d}$} & \multirow{3}{*}{$\begin{array}{l}0.5 \\
0.5\end{array}$} & \multicolumn{2}{|r|}{$P$-value } & 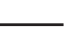 \\
\hline Basal DM eaten ${ }^{4}$ & 25.0 & 24.3 & 23.2 & 24.0 & & 0.04 & 0.67 & 0.20 \\
\hline Total DM input ${ }^{5}$ & 25.0 & 24.8 & 24.2 & 25.0 & & 0.20 & 0.67 & 0.20 \\
\hline Galacturonic acid & & - & & & & & & \\
\hline Infused & 0 & 346 & 693 & 0 & - & - & - & - \\
\hline Fecal output & 43 & 48 & 52 & 49 & 3.0 & 0.05 & 0.93 & 0.35 \\
\hline Apparent digestibility ${ }^{6}$ & & 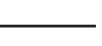 & & & & & & \\
\hline $\mathrm{DM}$ & 57.5 & 55.5 & 51.8 & 56.3 & 3.7 & 0.21 & 0.81 & 0.31 \\
\hline $\mathrm{OM}$ & 61.4 & 59.3 & 56.1 & 59.7 & 3.4 & 0.22 & 0.85 & 0.36 \\
\hline Starch & 93.2 & 92.2 & 91.9 & 91.5 & 1.0 & 0.31 & 0.75 & 0.72 \\
\hline $\mathrm{ADF}$ & 35.3 & 31.8 & 22.7 & 32.5 & 7.0 & 0.17 & 0.68 & 0.26 \\
\hline NDF & 33.3 & 26.9 & 20.0 & 28.7 & 7.6 & 0.18 & 0.98 & 0.34 \\
\hline $\mathrm{NDS}^{7}$ & 66.5 & 65.8 & 62.8 & 66.3 & 2.5 & 0.22 & 0.63 & 0.25 \\
\hline $\mathrm{NDSF}^{8}$ & 39.4 & 50.4 & 43.6 & 49.8 & 5.3 & 0.48 & 0.15 & 0.33 \\
\hline Apparently digested ${ }^{6}$ & & -1 & & & & & & \\
\hline $\mathrm{DM}$ & 14.5 & 13.8 & 12.5 & 14.1 & 1.0 & 0.14 & 0.77 & 0.20 \\
\hline $\mathrm{OM}$ & 14.0 & 13.4 & 12.3 & 13.6 & 0.9 & 0.14 & 0.80 & 0.23 \\
\hline Starch & 6.57 & 6.33 & 6.00 & 6.27 & 0.1 & 0.006 & 0.61 & 0.05 \\
\hline $\mathrm{ADF}$ & 1.66 & 1.42 & 0.96 & 1.51 & 0.36 & 0.14 & 0.74 & 0.22 \\
\hline $\mathrm{NDF}$ & 2.29 & 1.89 & 1.33 & 1.95 & 0.52 & 0.16 & 0.87 & 0.32 \\
\hline NDS & 12.2 & 11.9 & 11.1 & 12.2 & 0.49 & 0.11 & 0.67 & 0.12 \\
\hline NDSF & 1.04 & 1.40 & 1.40 & 1.30 & 0.16 & 0.11 & 0.27 & 0.59 \\
\hline $\mathrm{NDF}+\mathrm{NDSF}$ & 3.32 & 3.29 & 2.73 & 3.26 & 0.63 & 0.41 & 0.66 & 0.46 \\
\hline
\end{tabular}

${ }^{1}$ Treatments: 0 Pectin = abomasal infusion of saline only; 0.5 Pectin $=$ abomasal infusion of $0.5 \mathrm{~kg} / \mathrm{d}$ pectin in saline; 1 Pectin = abomasal infusion of $1.0 \mathrm{~kg} / \mathrm{d}$ pectin in saline; $1 \mathrm{Mol}=$ abomasal infusion of saline only and $1.0 \mathrm{~kg} / \mathrm{d}$ dried molasses was added to ration.

${ }^{2}$ Pre-planned contrasts tested the linear and quadratic effects of pectin infusion (0 Pectin, 0.5 Pectin, 1 Pectin) as well as the site of fermentation (1 Pectin vs. 1 Mol to test for hindgut vs. rumen fermentation).

${ }^{3}$ Standard error of the difference between treatment means.

${ }^{4}$ Intake of the basal ration only, not including pectin infused or molasses intake.

${ }^{5}$ Intake of the basal ration plus pectin infused or molasses intake.

${ }^{6}$ Calculations include infusion of pectin and intake of molasses and based on utilizing La as a marker.

${ }^{7}$ Neutral detergent soluble material.

${ }^{8}$ Neutral detergent soluble fiber (Hall et al., 1999).

reduction in intake; this is supported by the lack of difference between the basal ration intake for 1 Pectin vs. $1 \mathrm{Mol}$. Based on in vitro VFA production rates (Sunvold et al., 1995), 1 Pectin fermentation in the hindgut should have produced 1.3 Mcal of VFA energy from GalA degradation. Although data is lacking in dairy cows, studies in sheep (Myers et al., 1967; Faichney, 1969) and a review of multiple species (Engelhardt and Rechkemmer, 1983) suggest that VFA produced in the hindgut are nearly quantitatively absorbed. Fecal output of VFA accounted for 1.0 and $1.2 \mathrm{Mcal} / \mathrm{d}$ for treatments 0 Pectin and 1 Pectin, respectively. If this difference of $0.2 \mathrm{Mcal} / \mathrm{d}$ was due to incomplete absorption of VFA produced from pectin, hindgut degradation of GalA from the 1 Pectin treatment provided approximately 1.1 Mcal/d of absorbed VFA energy. An additional 0.5 $\mathrm{Mcal} / \mathrm{d}$ should have been provided by glucose in the infused pectin. Therefore, the 1 Pectin infusion pro- vided approximately $1.6 \mathrm{Mcal} / \mathrm{d}$, equivalent to $1.0 \mathrm{~kg}$ of the basal ration. The molasses in the $1 \mathrm{Mol}$ treatment should have also provided $1.6 \mathrm{Mcal} / \mathrm{d}$ (NRC, 2001). Feed restriction may not have been severe enough to promote complete consumption of the basal ration with the additional energy supplied by pectin or molasses. It is also possible that the reduction in intake with pectin infusion was due to the viscosity of the pectin itself. A review of human studies noted that dietary inclusion of viscous fibers such as pectin reduced voluntary energy intake due to slower gastric emptying and intestinal transit times (Burton-Freeman, 2000). Physical regulation of intake in ruminants is believed to occur primarily in the reticulorumen, and a reduced rate of abomasal emptying should increase reticulorumen fill and reduce intake (Allen, 2000). If pectin increased abomasal and postruminal digesta viscosity, it may have also de- 
Table 4. Experiment 2: Effect of abomasal pectin infusion on intake and digestion $(\mathrm{n}=6)$.

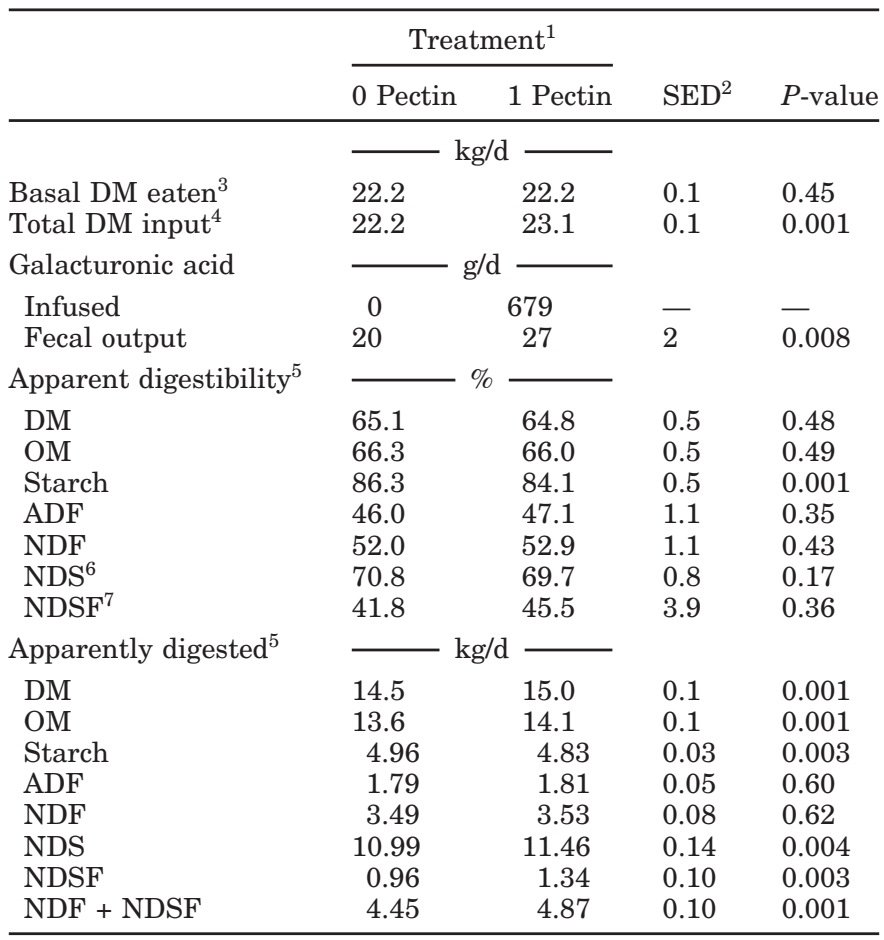

${ }^{1}$ Treatments: 0 Pectin = abomasal infusion of saline only; 1 Pectin $=$ abomasal infusion of $1.0 \mathrm{~kg} / \mathrm{d}$ pectin in saline.

${ }^{2}$ Standard error of the difference between treatment means.

${ }^{3}$ Intake of the basal ration only, not including pectin infused.

${ }^{4}$ Intake of the basal ration plus pectin infused.

${ }^{5}$ Calculations include pectin infused.

${ }^{6}$ Neutral detergent soluble material.

${ }^{7}$ Neutral detergent soluble fiber (Hall et al., 1999).

creased abomasal emptying and consequently reduced intake.

A more severe feed restriction protocol was used in the second experiment to prevent intake differences. As a result, basal ration intake for both 0 Pectin and 1 Pectin was not different (Table 4). Total input including pectin was significantly different as planned $(P<0.001)$.

Galacturonic acid, the primary component sugar of pectin, was analyzed in feces to determine extent of digestion of the infused pectin (Tables 3 and 4). In experiment 1, fecal excretion of GalA increased linearly with pectin infusion by $9 \mathrm{~g} / \mathrm{d}(P=0.05)$. These results suggest that of the $693 \mathrm{~g} / \mathrm{d}$ of GalA infused for 1 Pectin, only $9 \mathrm{~g}$ was undigested whereas the other $684 \mathrm{~g}$ were digested. Intestinal bacteria therefore degraded about $99 \%$ of the infused pectin, and this is in agreement with data from monogastrics (Cummings et al., 1979; Buchanan et al., 1994). Results were similar for experiment 2 with only $1 \%$ of infused GalA recovered in feces.

Apparent total tract digestibilities of $\mathrm{DM}$, OM, starch, ADF, NDF, neutral detergent solubles (NDS), and NDSF are listed in Tables 3 and 4 for experiments 1 and 2, respectively. Digestibilities in experiment 1 were calculated from recovery of La marker whereas experiment 2 used total collection. Although digestibilities of DM, OM, starch, ADF, NDF, and NDS were numerically reduced with pectin infusion in experiment 1 , these differences were not significant. However, the numeric decrease in apparent digestibilities combined with the significant decrease in basal diet DMI with the pectin infusion resulted in tendencies for reduced digested amounts $(\mathrm{kg} / \mathrm{d})$ of DM, OM, ADF, and NDS, and a significant reduction in starch digested $(P=$ 0.006). The effect of site of fermentation, molasses in the rumen or pectin in the intestines, did not affect digestibility with the exception of digested amount of starch being less for 1 Pectin vs. $1 \mathrm{Mol}(P=0.05)$. In experiment 2 , starch digestibility was reduced with pectin infusion $(P<0.001)$; however, digestibilities of DM, $\mathrm{OM}, \mathrm{ADF}, \mathrm{NDF}$, and NDS were unaffected. Starch digested was reduced with the pectin infusion $(P=0.003)$ as occurred in experiment 1 , but digested amounts of $\mathrm{DM}$ and $\mathrm{OM}$ were increased with the pectin infusion $(P<0.001)$ due to the increase in total DM input.

In experiment 1 , total tract apparent digestibilities of DM, OM, ADF, and NDF were unexpectedly low, and this did not occur in experiment 2. Digested amounts of NDF, NFC, fatty acids, and CP in experiment 1 were calculated by subtracting fecal flows from intakes. Because fecal fatty acids were not measured, fecal fatty acid flow was assumed to be zero. Digested energy flows were calculated from the digested amounts based on NRC (2001):

$$
\begin{gathered}
\text { Digested energy }(\mathrm{Mcal} / \mathrm{d})=\text { Digested NDF }(\mathrm{kg} / \mathrm{d}) \\
\times 4.2 \mathrm{Mcal} / \mathrm{kg}+\text { digested } \mathrm{NFC}(\mathrm{kg} / \mathrm{d}) \times 4.2 \mathrm{Mcal} / \mathrm{kg} \\
+ \text { digested fatty acids }(\mathrm{kg} / \mathrm{d}) \times 9.4 \mathrm{Mcal} / \mathrm{kg} \\
+ \text { digested } \mathrm{CP}(\mathrm{kg} / \mathrm{d}) \times 5.6 \mathrm{Mcal} / \mathrm{kg} .
\end{gathered}
$$

Dietary supply of metabolizable energy was calculated from digested energy, and supply of $\mathrm{NE}_{\mathrm{L}}$ was calculated from metabolizable energy according to NRC (2001) equations 2-10 and 2-12, respectively. Required $\mathrm{NE}_{\mathrm{L}}$ for milk production was calculated from production data according to equation 2-16 and $\mathrm{NE}_{\mathrm{L}}$ for maintenance was calculated as $0.080 \mathrm{Mcal} / \mathrm{kg}$ of $\mathrm{BW}^{0.75}$ (NRC, 2001). Energy balance was calculated as the difference between intake and requirements and was $-5.6,-3.1$, -7.9 , and $-2.6 \mathrm{Mcal} / \mathrm{d}$ for treatments 0 Pectin, $0.5 \mathrm{Pec}-$ tin, 1 Pectin, and $1 \mathrm{Mol}$, respectively. If these energy balances were correct, cows would be predicted to lose an average of $1 \mathrm{~kg} / \mathrm{d}$ during the course of the experiment, or $55 \mathrm{~kg}$ in total. Mean BW actually increased 
by $16 \mathrm{~kg}$ during the experiment. It is likely that fecal outputs were overestimated in trial 1 . This would have resulted in calculated low apparent digestibilities and negative energy balances.

Apparent total tract starch digestibility in experiment 1 averaged $92.2 \%$ of starch intake, whereas in experiment 2, digestibility was lower, averaging $85.2 \%$. For both experiments, corn grain provided approximately $53 \%$ of dietary starch and the difference in digestibility between experiments is likely explained by differences in corn grain density. Steam-rolled corn was $0.39 \mathrm{~kg}$ of DM/L in experiment 1 and $0.55 \mathrm{~kg}$ of DM/L in experiment 2 . When steam-flaked corn grain was replaced by dry-rolled corn, density increased from 0.39 to $0.52 \mathrm{~kg} / \mathrm{L}$ and apparent total tract starch digestibility decreased from 96.8 to $76.7 \%$ (Plascencia and Zinn, 1996). Similarly, Crocker et al. (1998) observed a decline in starch digestibility from 90.9 to $77.8 \%$ as steamflaked corn grain with a density of 0.39 was replaced by dry-rolled corn with a density of $0.54 \mathrm{~kg} / \mathrm{L}$.

Results from both experiments suggest that abomasal pectin reduced digestion of starch from the basal diet. Pectin was applied postruminally, so the reduction is likely due to an effect on postruminal starch digestion. One possibility is that pectin may have increased digesta viscosity in the small intestine, and this may have reduced amylolytic activity. Data is limited, but a study in rats found that feeding pectin did not affect starch digestibility although DM digestibility was significantly reduced with pectin (Brunsgaard et al., 1995). Another possibility is that pectin infusion may have reduced large intestinal starch digestion. Using cows with ileal cannulas, Knowlton et al. (1998) found that starch digestion in the large intestine ranged from 4 to $23 \%$ of starch intake. If large intestinal flow and digestion of starch from the basal diet was high, the pectin infused may have reduced intestinal fermentation of cornstarch. Many of the predominant intestinal microbes are capable of degrading both starch and pectin (Forsberg et al., 1997). Perhaps microbes preferentially digested infused pectin instead of the less digestible residual cornstarch, reducing total tract starch digestibility.

In experiment 1 , digestibilities of $\mathrm{DM}, \mathrm{OM}, \mathrm{ADF}$, $\mathrm{NDF}$, and NDS were numerically reduced with pectin infusion. Pectin may have limited digestion and consequently energy available to the animal from the basal diet. This suggests that pectin may have had a negative impact on the energy efficiency of the animal either because of increased hindgut fermentation or by some other impact of pectin on intestinal digestion. However, except for starch, pectin effects on digestibility were not observed in experiment 2 . It is possible that the differences between experiments were due to differ- ences in length of the infusion period, $9 \mathrm{~d}$ for experiment 1 and $11 \mathrm{~d}$ for experiment 2. Fecal sampling began after 6 and $9 \mathrm{~d}$ of infusion for experiments 1 and 2, respectively. When rats were switched from a commercial diet to a diet containing $8 \%$ pectin, digestibilities of both DM and starch were immediately reduced but then increased with time so that digestibility was stabilized after 8 and $4 \mathrm{~d}$, respectively (Brunsgaard et al., 1995). It is possible that cows did not have adequate time to adapt to the pectin infusion in experiment 1 and this led to the reduced nutrient digestibilities.

In both experiments, NDSF digestibility was low and not significantly increased with pectin infusion. Neutral detergent soluble fiber contains highly degradable plant fractions, primarily fructans, pectic substances, and $\beta$-glucans (Hall et al., 1999). Therefore, digestibility should have been greater than the 40 to $50 \%$ reported in Tables 3 and 4. Moreover, galacturonic acid, the predominant source of NDSF in the infused pectin, was completely degraded but this was not reflected by any treatment differences in NDSF digestibility. Ariza et al. (2001) found that isolated ruminal bacteria contained material that analyzed as NDSF, accounting for 6 to $8.5 \%$ of bacteria DM. The low apparent NDSF digestibilities in the present experiments are likely due to this artifact inflating the prediction of fecal NDSF.

The premise of these experiments was that pectin infusion would increase digested amounts of NDSF without affecting NDF digestion. Therefore, digestion of NDS (which includes NDSF) and total fiber (NDF + NDSF) should have increased, as was observed in experiment 2 (Table 4). However, in experiment 1, digested NDF was numerically reduced by $0.96 \mathrm{~kg} / \mathrm{d}$ with 1 Pectin compared with 0 Pectin (Table 3). Instead of increasing with pectin infusion, digested NDS actually tended to decrease by $1.1 \mathrm{~kg} / \mathrm{d}(P=0.11)$. Although digested NDSF tended to increase by $0.36 \mathrm{~kg} / \mathrm{d}$ with the pectin infusion $(P=0.11)$, total fiber digested was not affected by treatment and numerically decreased by $0.59 \mathrm{~kg} / \mathrm{d}$ for 1 Pectin. On typical lactation diets, a high proportion of NDF digestion (up to $50 \%$ of total tract NDF digestion) can occur in the hindgut (Firkins, 1997). It is possible that the pectin infusion reduced postruminal NDF digestion in experiment 1 . This could have resulted in the lack of treatment differences in total fiber digested but does not explain the tendency for reduced NDS digestion.

\section{Milk Production and Composition}

There were no significant differences in milk yield for either experiment (Tables 5 and 6). In experiment 2,1 Pectin significantly decreased milk fat percentage $(P=0.01)$ and tended to decrease milk fat yield $(P=$ 
Table 5. Experiment 1: Effect of abomasal pectin infusion or ruminal molasses on milk production and composition $(\mathrm{n}=3)$.

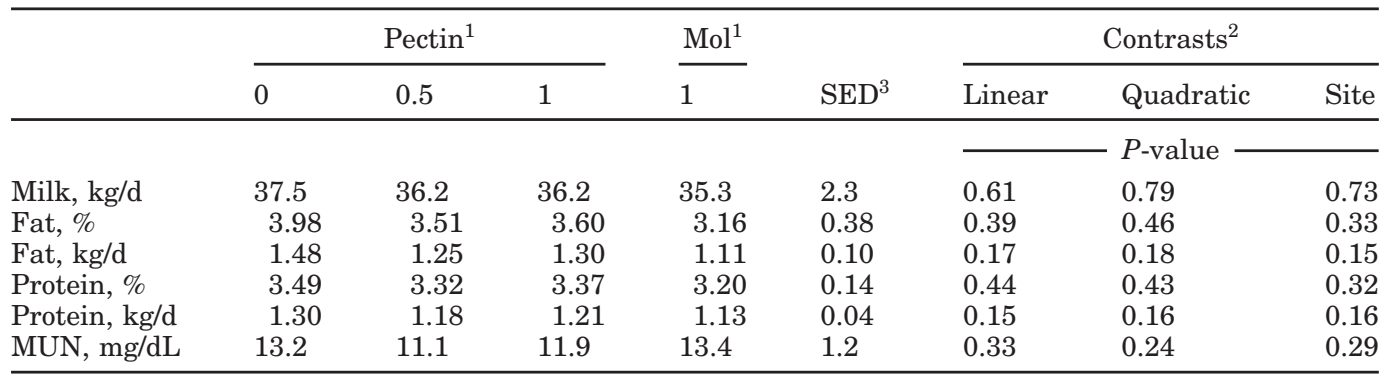

${ }^{1}$ Treatments: 0 Pectin $=$ abomasal infusion of saline only; 0.5 Pectin $=$ abomasal infusion of $0.5 \mathrm{~kg} / \mathrm{d}$ pectin in saline; 1 Pectin = abomasal infusion of $1.0 \mathrm{~kg} / \mathrm{d}$ pectin in saline; $1 \mathrm{Mol}=$ abomasal infusion of saline only and $1.0 \mathrm{~kg} / \mathrm{d}$ dried molasses was added to ration.

${ }^{2}$ Preplanned contrasts tested the linear and quadratic effects of pectin infusion (0 Pectin, 0.5 Pectin, 1 Pectin) as well as the site of fermentation (1 Pectin vs. 1 Mol to test for hindgut vs. rumen fermentation).

${ }^{3}$ Standard error of the difference between treatment means.

0.08). In experiment 1 , there was a similar but nonsignificant drop in milk fat with pectin infusion. Compared with 1 Pectin, $1 \mathrm{Mol}$ did not affect milk fat, although values for percent and yield were numerically lowest for $1 \mathrm{Mol}$. The effect of pectin infusion on milk fat was unexpected and suggests that postruminal fermentation may play a role in milk fat depression as has been indicated for ruminal fermentation (Griinari et al., 1998).

It was hypothesized that postruminal pectin fermentation would increase conversion of blood urea $\mathrm{N}$ to bacterial protein. Consequently, MUN was predicted to decrease with abomasal pectin. However, MUN was not significantly affected by treatment, suggesting that changes in the blood urea pool due to pectin infusion either did not occur or were too small to affect MUN.

\section{Nitrogen Balance}

At the same basal ration intake, pectin infusion was expected to increase intestinal microbial protein synthesis from blood urea $\mathrm{N}$, thereby increasing fecal $\mathrm{N}$

Table 6. Experiment 2: Effect of abomasal pectin infusion on milk production and composition $(\mathrm{n}=6)$.

\begin{tabular}{|c|c|c|c|c|}
\hline & \multicolumn{2}{|c|}{ Treatment $^{1}$} & \multirow[b]{2}{*}{$\mathrm{SED}^{2}$} & \multirow[b]{2}{*}{$P$-value } \\
\hline & 0 Pectin & 1 Pectin & & \\
\hline Milk, kg/d & 29.4 & 28.9 & 0.8 & 0.56 \\
\hline Fat, \% & 3.69 & 3.53 & 0.06 & 0.01 \\
\hline Fat, kg/d & 1.09 & 1.02 & 0.04 & 0.08 \\
\hline Protein, \% & 3.33 & 3.36 & 0.03 & 0.41 \\
\hline Protein, kg/d & 0.98 & 0.97 & 0.02 & 0.61 \\
\hline MUN, mg/dL & 11.9 & 11.2 & 0.6 & 0.29 \\
\hline
\end{tabular}

\footnotetext{
${ }^{1}$ Treatments: 0 Pectin $=$ abomasal infusion of saline only; 1 Pectin = abomasal infusion of $1.0 \mathrm{~kg} / \mathrm{d}$ pectin in saline.

${ }^{2}$ Standard error of the difference between treatment means.
}

and decreasing urinary N. Due to the pectin effect on basal ration intake in experiment 1 , pectin infusion tended to linearly $(P=0.06)$ reduce $\mathrm{N}$ intake by $42 \mathrm{~g} /$ d (Table 7). Independent of pectin effects, one would expect this drop in $\mathrm{N}$ intake to reduce urinary $\mathrm{N}$ and to a lesser extent fecal $\mathrm{N}$ (Wright et al., 1998). There was a tendency for the pectin infusion to linearly decrease urinary $\mathrm{N}$ by $26 \mathrm{~g} / \mathrm{d}(P=0.07)$; however, pectin actually tended to increase fecal $\mathrm{N}$ by $46 \mathrm{~g} / \mathrm{d}(P=0.10)$. Pectin also tended to linearly increase the fraction of intake $\mathrm{N}$ that was excreted in the feces $(P=0.06)$ and to decrease the proportion of urinary $\mathrm{N}$ in total urinary and fecal N $(P=0.11)$. These results suggest that independent of intake effects, pectin was able to increase postruminal bacterial growth and therefore fecal N. Compared with 1 Pectin, $1 \mathrm{Mol}$ had a similar $\mathrm{N}$ intake $(P=$ $0.20)$, but tended to have decreased fecal N $(P=0.14)$, increased urinary $\mathrm{N}(P=0.11)$, decreased fecal $\mathrm{N}$ as a fraction of intake $\mathrm{N}(P=0.10)$, and increased urinary $\mathrm{N}$ as a fraction of excreted $\mathrm{N}(P=0.14)$. These results demonstrate that the effects of pectin on $\mathrm{N}$ excretion were dependent on increasing postruminal fermentation. The $1 \mathrm{Mol}$ treatment should have diluted dietary protein and supplied additional VFA to a similar extent as 1 Pectin; however, effects on nitrogen excretion were unique to 1 Pectin.

In experiment 1, nitrogen was analyzed on both frozen and oven dried fecal samples to predict $\mathrm{N}$ losses due to drying. Nitrogen in the dried sample was, on average, $97.7 \%$ (SD $=3.4 \%$ ) of the level found in the frozen sample with no effect due to treatment (data not shown). Fecal $\mathrm{N}$ outputs are therefore underestimated by approximately $2.3 \%$ due to $\mathrm{N}$ volatilization during oven drying in experiment 1 . Underestimation of fecal $\mathrm{N}$ outputs due to freeze drying of feces in experiment 
Table 7. Experiment 1: Effect of abomasal pectin infusion or ruminal molasses on intake and excretion of nitrogen $(\mathrm{n}=3)$.

\begin{tabular}{|c|c|c|c|c|c|c|c|c|}
\hline & \multicolumn{3}{|c|}{ Pectin $^{1}$} & \multirow{2}{*}{$\frac{\mathrm{Mol}^{1}}{1}$} & \multirow[b]{2}{*}{$\mathrm{SED}^{3}$} & \multicolumn{3}{|c|}{ Contrasts $^{2}$} \\
\hline & 0 & 0.5 & 1 & & & Linear & Quadratic & Site \\
\hline & \multicolumn{4}{|c|}{ g of $N / d$} & & & \multicolumn{2}{|l|}{$P$-value } \\
\hline Intake & 665 & 643 & 623 & 647 & 15 & 0.06 & 0.98 & 0.20 \\
\hline Milk & 196 & 180 & 190 & 185 & 9 & 0.60 & 0.22 & 0.66 \\
\hline Feces $^{4}$ & 279 & 301 & 325 & 287 & 19 & 0.10 & 0.98 & 0.14 \\
\hline Urine $^{5}$ & 277 & 264 & 251 & 272 & 9 & 0.07 & 0.97 & 0.11 \\
\hline Retained $^{6}$ & -87 & -102 & -143 & -97 & 22 & 0.08 & 0.54 & 0.13 \\
\hline Fecal N/intake N & 43.3 & 46.9 & 51.6 & 44.7 & 2.9 & 0.06 & 0.84 & 0.10 \\
\hline Apparent $\mathrm{N}$ digestibility & 56.7 & 53.1 & 48.4 & 55.3 & 2.9 & 0.06 & 0.84 & 0.10 \\
\hline Fecal N/fecal DM & 2.68 & 2.74 & 2.77 & 2.65 & 0.04 & 0.10 & 0.64 & 0.05 \\
\hline Urine N/intake N & 41.8 & 41.2 & 40.6 & 41.8 & 1.2 & 0.39 & 0.98 & 0.38 \\
\hline Urine $N /($ fecal $N+$ urine $N)$ & 49.3 & 46.8 & 43.6 & 48.6 & 2.5 & 0.11 & 0.87 & 0.14 \\
\hline Urine $\mathrm{N}, \mathrm{g} / \mathrm{L}$ & 7.82 & 7.37 & 7.08 & 7.26 & 0.23 & 0.05 & 0.71 & 0.48 \\
\hline
\end{tabular}

\footnotetext{
${ }^{1}$ Treatments: 0 Pectin = abomasal infusion of saline only; 0.5 Pectin = abomasal infusion of $0.5 \mathrm{~kg} / \mathrm{d}$ pectin in saline; 1 Pectin = abomasal infusion of $1.0 \mathrm{~kg} / \mathrm{d}$ pectin in saline; $1 \mathrm{Mol}=$ abomasal infusion of saline only and $1.0 \mathrm{~kg} / \mathrm{d}$ dried molasses was added to ration.

${ }^{2}$ Preplanned contrasts tested the linear and quadratic effects of pectin infusion (0 Pectin, 0.5 Pectin, 1 Pectin) as well as the site of fermentation (1 Pectin vs. 1 Mol to test for hindgut vs. rumen fermentation).

${ }^{3}$ Standard error of the difference between treatment means.

${ }^{4} \mathrm{Fecal}$ output predicted using $\mathrm{La}$ as a marker.

${ }^{5}$ Urinary output predicted from creatinine concentration.

${ }^{6} \mathrm{Nitrogen}$ retained $=$ intake $\mathrm{N}-$ milk $\mathrm{N}-$ urine $\mathrm{N}-$ fecal $\mathrm{N}$.
}

2 was not measured but was likely less than or equal to that found in experiment 1 .

In experiment 2 , there was no effect of pectin infusion on $\mathrm{N}$ intake (Table 8). Therefore, effects on $\mathrm{N}$ excretion should be entirely due to increasing fermentable substrate load to the intestines. Pectin infusion significantly decreased urinary $\mathrm{N}$ by $27 \mathrm{~g} / \mathrm{d}(P=0.002)$ and

Table 8. Experiment 2: Effect of abomasal pectin infusion on intake and excretion of nitrogen $(n=6)$.

\begin{tabular}{|c|c|c|c|c|}
\hline & \multicolumn{2}{|c|}{ Treatment $^{1}$} & \multirow[b]{2}{*}{$\mathrm{SED}^{2}$} & \multirow[b]{2}{*}{$P$-value } \\
\hline & 0 Pectin & 1 Pectin & & \\
\hline & \multicolumn{2}{|c|}{$-\mathrm{g}$ of $\mathrm{N} / \mathrm{d}-$} & & \\
\hline Intake & 615 & 616 & 2 & 0.41 \\
\hline Milk & 156 & 153 & 4 & 0.45 \\
\hline Feces & 209 & 231 & 5 & 0.001 \\
\hline Urine & 230 & 203 & 8 & 0.002 \\
\hline Retained $^{3}$ & 20 & 30 & 8 & 0.24 \\
\hline Fecal N/intake N & 34.0 & 37.5 & 0.8 & 0.001 \\
\hline Apparent $\mathrm{N}$ digestibility & 66.0 & 62.5 & 0.8 & 0.001 \\
\hline Fecal N/fecal DM & 2.69 & 2.84 & 0.14 & 0.001 \\
\hline Urine N/intake $\mathrm{N}$ & 37.6 & 33.0 & 1.1 & 0.001 \\
\hline Urine $\mathrm{N} /($ fecal $\mathrm{N}+$ urine $\mathrm{N})$ & 52.3 & 46.6 & 0.7 & 0.001 \\
\hline Urine $\mathrm{N}, \mathrm{g} / \mathrm{L}$ & 6.38 & 5.75 & 0.16 & 0.001 \\
\hline
\end{tabular}

\footnotetext{
${ }^{1}$ Treatments: 0 Pectin = abomasal infusion of saline only; 1 Pectin = abomasal infusion of $1.0 \mathrm{~kg} / \mathrm{d}$ pectin in saline.

${ }^{2}$ Standard error of the difference between treatment means.

${ }^{3}$ Nitrogen retained $=$ intake $\mathrm{N}-$ milk $\mathrm{N}-$ urine $\mathrm{N}-$ fecal $\mathrm{N}$.
}

increased fecal $\mathrm{N}$ by $22 \mathrm{~g} / \mathrm{d}(P<0.001)$. Consequently, the fraction of intake $\mathrm{N}$ excreted in feces increased $(P$ $<0.001$ ), the fraction of intake $\mathrm{N}$ excreted in the urine decreased $(P<0.001)$, and the portion of urine and fecal $\mathrm{N}$ that was from urine decreased $(P<0.001)$. Moreover, the urinary concentration of $\mathrm{N}$ decreased and the fecal concentration of $\mathrm{N}$ increased $(P<0.001)$ with pectin infusion.

In both experiments, abomasal pectin decreased urinary $\mathrm{N}$ and increased fecal $\mathrm{N}$. Intestinal pectin supplied energy for microbial growth and it is likely that circulating urea supplied at least some of the $\mathrm{N}$ required for microbial growth, thereby reducing urinary $\mathrm{N}$ excretion. Similar effects of hindgut fermentation on nitrogen excretion have been demonstrated in monogastrics and in sheep. Replacing 8 to $10 \%$ of digestible carbohydrates with pectin increased fecal $\mathrm{N}$ output and decreased urinary $\mathrm{N}$ output in rats (Brunsgaard et al., 1995; Pastuszewska et al., 2000). In sheep, cecal infusions of $50 \mathrm{~g} / \mathrm{d}$ of pectin increased fecal $\mathrm{N}$ from 6.1 to $7.6 \mathrm{~g} / \mathrm{d}$ and decreased urinary $\mathrm{N}$ from 11.4 to $10.1 \mathrm{~g} / \mathrm{d}$ (Mason et al., 1981). Mason et al. (1981) contend that the increase in fecal $\mathrm{N}$ was primarily due to increased fecal bacteria $\mathrm{N}$ as was evidenced by increased fecal outputs of both 2,6-diaminopimelic acid and amino acid $\mathrm{N}$. Shifts of $\mathrm{N}$ from urine to feces have also been observed in sheep infused into the terminal ileum with starch (Ørskov et al., 1970) or glucose (Thornton et al., 
1970) or into the cecum with starch (Mason et al., 1981; Surra et al., 1997). The increase in fecal N reported by Thornton et al. (1970) was mirrored by a drop in urinary urea $\mathrm{N}$, suggesting that intestinal bacteria converted urea $\mathrm{N}$ into fecal $\mathrm{N}$. All of these studies were with animals fed near maintenance, but Reynolds et al. (2001) found that abomasal infusion of 0 to $1200 \mathrm{~g} / \mathrm{d}$ wheat starch in lactating dairy cows significantly reduced urinary $\mathrm{N}$, which they suggest was due to increased intestinal fermentation. Together with the current experiments, these results demonstrate that both maintenance-fed animals and dairy cows fed at 3.5 times maintenance or greater can ferment carbohydrates in the hindgut, and this can change the pattern of $\mathrm{N}$ excretion.

Nocek and Russell (1988) suggested that substrates fermented rapidly in the rumen yield more MCP than do slowly fermented substrates due to a relative reduction in bacterial maintenance requirements at rapid rates of growth. In these experiments, abomasal pectin was highly fermentable as evidenced by the lack of fecal GalA recovery (Tables 3 and 4). It is possible that abomasal pectin reduced postruminal fermentation of less digestible substrates such as starch or NDF. Therefore, part of the increase in fecal $\mathrm{N}$ with pectin infusion may have been due to increasing bacterial growth rates rather than just increasing total fermentable substrate.

The effects of abomasal pectin on $\mathrm{N}$ retention differed between experiments. For experiment 1, predicted nitrogen retention (Table 7) was negative for all treatments ( $\leq-87 \mathrm{~g}$ of $\mathrm{N} / \mathrm{d}$ ), suggesting that animals were in severe negative protein balance. It is likely that an overestimation of fecal output and, therefore, fecal $\mathrm{N}$ resulted in these negative protein balances. Despite the already negative values for $\mathrm{N}$ retention, pectin infusion tended to decrease $\mathrm{N}$ retention by $56 \mathrm{~g} / \mathrm{d}(P=0.08)$, and this effect tended to be specific to increasing postruminal fermentation ( $P=0.13$ for $1 \mathrm{Mol}$ vs. 1 Pectin). Souffrant (2001) hypothesized that the high viscosity of pectin reduces intestinal protein digestion and absorption by preventing the interaction of digesta with enzymes and microvilli. Abomasal pectin may have reduced postruminal digestion of rumen microbial or dietary protein, consequently reducing $\mathrm{N}$ retention. On the other hand, pectin may have reduced $\mathrm{N}$ retention by increasing endogenous true protein secretion or reducing intestinal reabsorption of endogenous N. A drop in true digestibility of dietary or endogenous protein with abomasal pectin may have also contributed to the decrease in urinary $\mathrm{N}$ and increase in fecal $\mathrm{N}$. It is possible that abomasal pectin increased fecal $\mathrm{N}$ at the expense of $\mathrm{N}$ required for production, increasing the draw of $\mathrm{N}$ from the body and decreasing $\mathrm{N}$ balance. However, pectin effects on $\mathrm{N}$ retention were not observed in experiment 2.

\section{Ruminal Characteristics}

For both experiments, interaction terms were not significant for any rumen parameters. In experiment 1 , there were no effects of treatment on rumen $\mathrm{pH}, \mathrm{NH}_{3}$, or VFA, or on urinary excretion of purine derivatives (Table 9). In experiment 2, there were no effects on rumen $\mathrm{pH}$ or VFA, although there were tendencies for reduced rumen $\mathrm{NH}_{3}(P=0.06)$ and urinary purine derivative excretion $(P=0.09)$ with pectin infusion (Table 10). Together, these results suggest that postruminal pectin may have reduced urea recycling to the rumen, consequently reducing rumen $\mathrm{NH}_{3}$ and MCP. The average rumen $\mathrm{NH}_{3}$ values were above the $3.6 \mathrm{mM}(5.0 \mathrm{mg}$ of $\mathrm{NH}_{3}-\mathrm{N} / \mathrm{dL}$ ) required for maximal microbial protein synthesis in vitro (Satter and Roffler, 1975). However, more recent evidence suggests that in vivo rumen $\mathrm{NH}_{3}$ requirements for maximal microbial protein synthesis can be greater than $7.2 \mathrm{mM}\left(10.0 \mathrm{mg}\right.$ of $\mathrm{NH}_{3}-\mathrm{N} / \mathrm{dL}$; Reynal et al., 2005). It is possible that MCP was limited by $\mathrm{NH}_{3}$ availability on the basal diet, and this may have been exacerbated by abomasal pectin infusion. The $4 \%$ decrease in urinary purine derivative excretion suggests that rumen MCP production was reduced by $4 \%$ with the pectin infusion. Although purine: $\mathrm{N}$ in rumen bacteria was not measured it is unlikely that treatment affected this ratio because the same basal diet was fed to both treatments. Despite effects on ruminal $\mathrm{NH}_{3}$ and urinary purine derivatives, 12 -h in situ digestibility of soy hulls did not differ between treatments.

\section{Fecal Characteristics}

Fecal output was increased with abomasal pectin in both experiments. In experiment 1 , fecal DM output was nonsignificantly increased by $1.3 \mathrm{~kg} / \mathrm{d}$ with pectin infusion (Table 11). In experiment 2 , pectin infusion significantly increased fecal DM output by $0.4 \mathrm{~kg} / \mathrm{d}(P=$ 0.002, Table 12). Mason et al. (1981) found that when they gave sheep cecal pectin infusions, fecal DM output increased, primarily due to increased fecal bacteria. Although bacteria were not measured in the current studies, fecal output of purines numerically increased with pectin infusion in experiment 1 and significantly increased in experiment $2(P<0.001)$. In experiment 2 , the concentration of fecal purines $(\mathrm{mmol} / \mathrm{kg}$ of fecal $\mathrm{DM})$ also increased $(P<0.001)$. Reported purine:N ratio in ruminal bacteria was used to predict fecal bacteria $\mathrm{N}$ from fecal purines. Average purine: $\mathrm{N}(\mathrm{mmol} / \mathrm{g})$ in mixed populations of ruminal bacteria ranges from 0.74 to 1.85 with a mean of 1.25 (Calsamiglia et al., 1996; 
Table 9. Experiment 1: Effect of abomasal pectin infusion or ruminal molasses on ruminal characteristics $(\mathrm{n}=3)$.

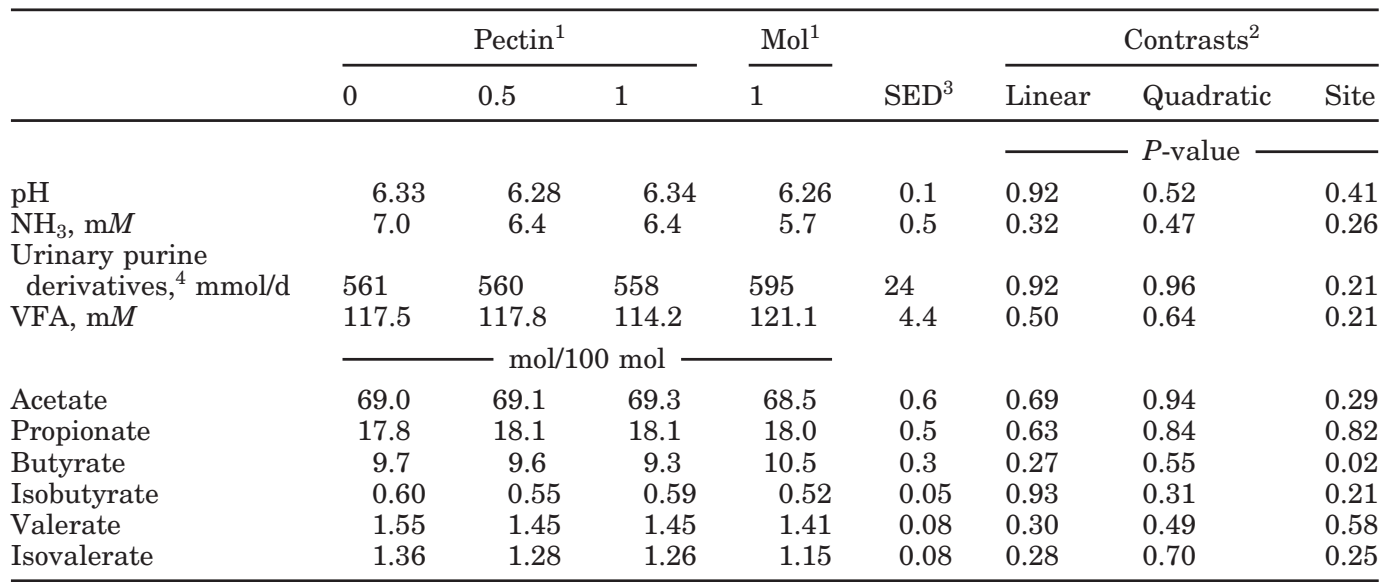

${ }^{1}$ Treatments: 0 Pectin = abomasal infusion of saline only; 0.5 Pectin = abomasal infusion of $0.5 \mathrm{~kg} / \mathrm{d}$ pectin in saline; 1 Pectin = abomasal infusion of $1.0 \mathrm{~kg} / \mathrm{d}$ pectin in saline; $1 \mathrm{Mol}=$ abomasal infusion of saline only and $1.0 \mathrm{~kg} / \mathrm{d}$ dried molasses was added to ration.

${ }^{2}$ Preplanned contrasts tested the linear and quadratic effects of pectin infusion (0 Pectin, 0.5 Pectin, 1 Pectin) as well as the site of fermentation (1 Pectin vs. 1 Mol to test for hindgut vs. rumen fermentation).

${ }^{3}$ Standard error of the difference between treatment means.

${ }^{4}$ Urinary excretion of allantoin and uric acid.

Vagnoni and Broderick, 1997; Obispo and Dehority, 1999; Rodríguez et al., 2000; Carro and Miller, 2002; Reynal et al., 2003; Vicente et al., 2004). Based on the mean and range of these values, the increased fecal purine output in experiment 2 with abomasal pectin should have been associated with an increase in fecal bacteria $\mathrm{N}$ of $17 \mathrm{~g}$ (range 12 to 29). Therefore, fecal bacteria were responsible for approximately $77 \%$ (range 55 to $>100$ ) of the $22 \mathrm{~g} / \mathrm{d}$ increase in fecal $\mathrm{N}$ with abomasal pectin infusion. The NRC (2001) predicts rumen
MCP as $130 \mathrm{~g} / \mathrm{kg}$ of discounted total digestible nutrients. Assuming similar microbial yields in the rumen and intestines, this can be used to calculate a predicted increase in fecal microbial $\mathrm{N}$ output due to the 1 Pectin treatment. Assuming no discount and $0.64 \mathrm{~kg}$ of intestinally fermentable total digestible nutrients from the 1 Pectin treatment, fecal microbial $\mathrm{N}$ from pectin alone is predicted to be $13 \mathrm{~g} / \mathrm{d}$, or $59 \%$ of the total increase in fecal N. This is similar to the $17 \mathrm{~g} / \mathrm{d}$ increase in fecal microbial $\mathrm{N}$ estimated from fecal purines. The

Table 10. Experiment 2: Effect of abomasal pectin infusion on ruminal characteristics $(n=6)$.

\begin{tabular}{|c|c|c|c|c|}
\hline & \multicolumn{2}{|c|}{ Treatment $^{1}$} & \multirow[b]{2}{*}{$\mathrm{SED}^{2}$} & \multirow[b]{2}{*}{$P$-value } \\
\hline & 0 Pectin & 1 Pectin & & \\
\hline $\mathrm{pH}$ & 6.44 & 6.45 & 0.03 & 0.90 \\
\hline $\mathrm{NH}_{3}, \mathrm{~m} M$ & 6.9 & 6.0 & 0.4 & 0.06 \\
\hline Urinary purine derivatives, ${ }^{3} \mathrm{mmol} / \mathrm{d}$ & 532 & 510 & 12 & 0.09 \\
\hline In situ NDF digestibility ${ }_{4}^{4} \%$ & 33.8 & 36.2 & 1.8 & 0.22 \\
\hline VFA, mM & 90.9 & 88.0 & 2.5 & 0.27 \\
\hline Acetate & 64.9 & 65.1 & 0.3 & 0.38 \\
\hline Propionate & 20.0 & 19.8 & 0.3 & 0.57 \\
\hline Butyrate & 10.0 & 9.9 & 0.2 & 0.35 \\
\hline Isobutyrate & 1.63 & 1.63 & 0.06 & 0.95 \\
\hline Valerate & 1.51 & 1.51 & 0.05 & 0.86 \\
\hline Isovalerate & 1.94 & 2.03 & 0.08 & 0.26 \\
\hline
\end{tabular}

\footnotetext{
${ }^{1}$ Treatments: 0 Pectin = abomasal infusion of saline only; 1 Pectin = abomasal infusion of $1.0 \mathrm{~kg} / \mathrm{d}$ pectin in saline.

${ }^{2}$ Standard error of the difference between treatment means.

${ }^{3}$ Urinary excretion of allantoin and uric acid.

${ }^{4}$ Determined as disappearance of NDF from soy hulls after a 12-h rumen incubation.
} 
Table 11. Experiment 1: Effect of abomasal pectin infusion or ruminal molasses on fecal characteristics $(\mathrm{n}=3)$.

\begin{tabular}{|c|c|c|c|c|c|c|c|c|}
\hline & \multicolumn{3}{|c|}{ Pectin $^{1}$} & \multicolumn{2}{|l|}{$\mathrm{Mol}^{1}$} & \multicolumn{3}{|c|}{ Contrasts $^{2}$} \\
\hline & 0 & 0.5 & 1 & 1 & $\mathrm{SED}^{3}$ & Linear & Quadratic & Site \\
\hline & & & & & & & $P$-value & \\
\hline $\mathrm{DM},{ }^{4} \mathrm{~kg} / \mathrm{d}$ & 10.4 & 11.0 & 11.7 & 10.8 & 0.8 & 0.22 & 0.91 & 0.35 \\
\hline $\mathrm{DM}, \%$ & 16.0 & 15.3 & 15.9 & 15.9 & 0.3 & 0.81 & 0.10 & 0.93 \\
\hline $\mathrm{pH}$ & 6.71 & 6.64 & 6.70 & 6.62 & 0.04 & 0.83 & 0.19 & 0.16 \\
\hline Purines, g/d & 15.4 & 17.2 & 18.2 & 16.2 & 1.8 & 0.23 & 0.83 & 0.35 \\
\hline & & 111001/ & 10 DIV & & & & & \\
\hline Purines & 10.4 & 10.9 & 11.0 & 10.4 & 1.1 & 0.64 & 0.86 & 0.62 \\
\hline $\mathrm{NH}_{3}$ & 20.5 & 20.5 & 20.9 & 20.9 & 4.3 & 0.93 & 0.96 & 0.99 \\
\hline VFA & 380 & 416 & 404 & 424 & 17 & 0.25 & 0.20 & 0.30 \\
\hline & & $-\mathrm{mol} / 1$ & $\mathrm{~mol}$ & & & & & \\
\hline Acetate & 75.0 & 77.3 & 77.5 & 77.0 & 1.2 & 0.11 & 0.37 & 0.65 \\
\hline Propionate & 14.4 & 13.3 & 12.8 & 13.4 & 0.4 & 0.03 & 0.48 & 0.26 \\
\hline Butyrate & 8.0 & 7.0 & 7.5 & 7.5 & 0.6 & 0.42 & 0.23 & 0.98 \\
\hline Isobutyrate & 0.71 & 0.57 & 0.46 & 0.56 & 0.10 & 0.08 & 0.84 & 0.41 \\
\hline Valerate & 1.29 & 1.28 & 1.29 & 1.21 & 0.14 & 0.99 & 0.96 & 0.62 \\
\hline Isovalerate & 0.63 & 0.55 & 0.45 & 0.40 & 0.12 & 0.24 & 0.90 & 0.73 \\
\hline
\end{tabular}

\footnotetext{
${ }^{1}$ Treatments: 0 Pectin = abomasal infusion of saline only; 0.5 Pectin = abomasal infusion of $0.5 \mathrm{~kg} / \mathrm{d}$ pectin in saline; 1 Pectin = abomasal infusion of $1.0 \mathrm{~kg} / \mathrm{d}$ pectin in saline; $1 \mathrm{Mol}=$ abomasal infusion of saline only and $1.0 \mathrm{~kg} / \mathrm{d}$ dried molasses was added to ration.

${ }^{2}$ Preplanned contrasts tested the linear and quadratic effects of pectin infusion (0 Pectin, 0.5 Pectin, 1 Pectin) as well as the site of fermentation (1 Pectin vs. 1 Mol to test for hindgut vs. rumen fermentation).

${ }^{3}$ Standard error of the difference between treatment means.

${ }^{4}$ Fecal DM output determined using La as a marker.
}

remaining portion of the $22 \mathrm{~g} / \mathrm{d}$ increase in fecal $\mathrm{N}$ is likely due to reductions in true protein digestibility or increases in endogenous protein losses with abomasal pectin.

A secondary objective for these experiments was to identify whether postruminal pectin digestion was re-

Table 12. Experiment 2: Effect of abomasal pectin infusion on fecal characteristics $(\mathrm{n}=6)$

\begin{tabular}{|c|c|c|c|c|}
\hline & \multicolumn{2}{|c|}{ Treatment $^{1}$} & \multirow[b]{2}{*}{$\mathrm{SED}^{2}$} & \multirow[b]{2}{*}{$P$-value } \\
\hline & 0 Pectin & 1 Pectin & & \\
\hline $\mathrm{DM}, \mathrm{kg} / \mathrm{d}$ & 7.8 & 8.2 & 0.1 & 0.002 \\
\hline $\mathrm{DM}, \%$ & 14.9 & 15.2 & 0.2 & 0.13 \\
\hline $\mathrm{pH}$ & 6.43 & 6.42 & 0.03 & 0.70 \\
\hline \multirow[t]{2}{*}{ Purines, g/d } & 15.4 & 18.5 & 0.4 & 0.001 \\
\hline & \multicolumn{4}{|c|}{ - $\mathrm{mmol} / \mathrm{kg}$ of fecal DM - } \\
\hline Purines & 13.8 & 15.8 & 0.3 & 0.001 \\
\hline $\mathrm{NH}_{3}$ & 19.8 & 13.4 & 1.1 & 0.001 \\
\hline VFA & 322 & 325 & 8 & 0.71 \\
\hline Acetate & 720 & 732 & 06 & 007 \\
\hline Propionate & 16.5 & 15.7 & 0.3 & 0.02 \\
\hline Butyrate & 9.1 & 8.8 & 0.4 & 0.47 \\
\hline Isobutyrate & 0.71 & 0.60 & 0.05 & 0.04 \\
\hline Valerate & 0.94 & 0.94 & 0.06 & 0.99 \\
\hline Isovalerate & 0.77 & 0.82 & 0.05 & 0.36 \\
\hline
\end{tabular}

${ }^{1}$ Treatments: 0 Pectin = abomasal infusion of saline only; 1 Pectin = abomasal infusion of $1.0 \mathrm{~kg} / \mathrm{d}$ pectin in saline.

${ }^{2}$ Standard error of the difference between treatment means. flected by changes in fecal characteristics. In the future, those characteristics might be used as markers to predict relative differences in postruminal fermentation. For example, fecal purine concentration was increased by abomasal pectin in the second experiment, so purine concentration might be one such marker. In rats, feeding pectin increased cecal VFA concentrations and reduced cecal ammonia concentration and $\mathrm{pH}$ (Rémésy and Demigné, 1989). Similarly, pectin reduced fecal $\mathrm{pH}$ in humans (Fleming et al., 1983) and reduced fecal DM percentage in rats (Armstrong et al., 1993). Consequently, fecal $\mathrm{pH}, \mathrm{DM}$ percentage, $\mathrm{NH}_{3}$, and VFA were measured as potential markers of pectin digestion.

Contrary to monogastric data, abomasal pectin did not affect fecal DM percentage in either experiment (Tables 11 and 12), although there was a tendency for a quadratic effect of pectin infusion $(P=0.10)$ in experiment 1. Pectin infusion also did not affect fecal $\mathrm{pH}$. Abomasal starch infusion in lactating cows has been shown to reduce fecal $\mathrm{pH}$, and this was attributed to postruminal fermentation of the infused starch (Reynolds et al., 2001). Perhaps effects of postruminal fermentation on fecal $\mathrm{pH}$ are substrate-specific. Fecal $\mathrm{N}$ as a percentage of fecal DM tended to increase with pectin infusion in experiment $1(P=0.10$, Table 7$)$ and significantly increased in experiment $2(P<0.001$, Table 8). In experiment 2 , fecal $\mathrm{NH}_{3}$ was significantly reduced with the pectin infusion $(P<0.001)$, suggesting that 
fecal $\mathrm{NH}_{3}$ may also reflect postruminal microbial activity. However, the lack of even a numerical effect in experiment 1 suggests limitations to the effectiveness of $\mathrm{NH}_{3}$ as a marker. The reduction in fecal $\mathrm{NH}_{3}$ in experiment 2 supports the hypothesis that postruminal pectin increased conversion of blood urea $\mathrm{N}$ into microbial protein. Circulating urea diffuses into the large intestine and is converted to ammonia by gut microbes. Pectin appears to have increased microbial uptake of available $\mathrm{NH}_{3}-\mathrm{N}$.

Total fecal VFA (mmol/kg of fecal DM) were not affected by abomasal pectin in either experiment (Tables 11 and 12). However, the molar proportion of acetate tended to increase $(P \leq 0.11)$ and the molar proportion of propionate significantly decreased $(P \leq 0.03)$ with pectin infusion in both experiments. In addition, the molar proportion of isobutyrate tended to decrease $(P=$ 0.08 ) with abomasal pectin in experiment 1 , and this effect was significant $(P=0.04)$ in experiment 2 . In the rumen, pectin fermentation primarily produces acetate, reducing the molar proportions of other VFA (Hatfield and Weimer, 1995; Ariza et al., 2001), and the same appears to be true in the hindgut.

\section{CONCLUSIONS}

The abomasal infusion of up to $1 \mathrm{~kg} / \mathrm{d}$ of citrus pectin reduced urinary $\mathrm{N}$ and increased fecal $\mathrm{N}$. As a proportion of total manure $\mathrm{N}$, urinary $\mathrm{N}$ tended to be reduced from 49.3 to $43.6 \%$ in experiment 1 , and was significantly reduced from 52.3 to $46.6 \%$ in experiment 2 for the 0 Pectin compared with 1 Pectin treatments. Reduced urinary $\mathrm{N}$ should reduce manure ammonia losses. These results were specific to increasing postruminal fermentation, as was evidenced by a lack of similar effects when molasses was included in the diet. Although MUN was not significantly reduced, pectin infusion reduced ruminal and fecal $\mathrm{NH}_{3}$ in experiment 2 , suggesting that pectin increased intestinal microbial protein production from blood urea N. Pectin increased production and concentration of fecal purines in experiment 2 , likely reflecting an increase in fecal microbial output. However, some of the increase in fecal $\mathrm{N}$ was not due to increased fecal microbial $\mathrm{N}$, and $\mathrm{N}$ balance was significantly reduced in experiment 1 , suggesting that postruminal pectin may have negatively influenced protein nutrition in addition to its effect on fecal microbial N. In total, these results suggest that feeding diets that increase postruminal carbohydrate fermentation may reduce ammonia volatilization from manure.

\section{ACKNOWLEDGMENTS}

The authors would like to thank the staff of the University of Wisconsin Dairy Cattle Center. Financial sup- port for this project was provided by US EPA Science to Achieve Results Program Grant \#915435 and from USDA formula funding as part of Regional project NC-1009.

\section{REFERENCES}

Allen, M. S. 2000. Effects of diet on short-term regulation of feed intake by lactating dairy cattle. J. Dairy Sci. 83:1598-1624.

Ariza, P., A. Bach, M. D. Stern, and M. B. Hall. 2001. Effects of carbohydrates from citrus pulp and hominy feed on microbial fermentation in continuous culture. J. Anim. Sci. 79:2713-2718.

Armstrong, E. F., M. A. Eastwood, and W. G. Brydon. 1993. The influence of wheat bran and pectin on the distribution of water in rat caecal contents and faeces. Br. J. Nutr. 69:913-920.

Association of Official Analytical Chemists. 1990. Official Methods of Analysis. Vol. I. 15th ed. AOAC, Arlington, VA.

Bal, M. A., R. D. Shaver, A. G. Jirovec, K. J. Shinners, and J. G. Coors. 2000. Crop processing and chop length of corn silage: Effects on intake, digestion, and milk production by dairy cows. J. Dairy Sci. 83:1264-1273.

Brunsgaard, G., K. E. Bach Knudsen, and B. O. Eggum. 1995. The influence of the period of adaptation on the digestibility of diets containing different types of indigestible polysaccharides in rats. Br. J. Nutr. 74:833-848.

Buchanan, C. J., S. C. Fry, and M. A. Eastwood. 1994. The metabolism and fate of [methyl-14C] and [uronate-6-14C] pectin-labelled dietary plant cell walls in the rat. J. Sci. Food Agric. 66:163-173.

Burton-Freeman, B. 2000. Dietary fiber and energy regulation. J. Nutr. 130:272S-275S.

Callison, S. L., J. L. Firkins, M. L. Eastridge, and B. L. Hull. 2001. Site of nutrient digestion by dairy cows fed corn of different particle sizes or steam-rolled. J. Dairy Sci. 84:1458-1467.

Calsamiglia, S., M. D. Stern, and J. L. Firkins. 1996. Comparison of nitrogen-15 and purines as microbial markers in continuous culture. J. Anim. Sci. 74:1375-1381.

Carro, M. D., and E. L. Miller. 2002. Comparison of microbial markers (15N and purine bases) and bacterial isolates for the estimation of rumen microbial protein synthesis. Anim. Sci. 75:315-321.

Chen, X. B., and M. J. Gomes. 1992. Estimation of microbial protein supply to sheep and cattle based on urinary excretion of purine derivatives-an overview of the technical details. International Feed Resources Unit, Rowett Research Institute, Aberdeen, UK.

Combs, D. K., and L. D. Satter. 1992. Determination of markers in digesta and feces by direct current plasma emission spectroscopy. J. Dairy Sci. 75:2176-2183.

Crocker, L. M., E. J. DePeters, J. G. Fadel, H. Perez-Monti, S. J. Taylor, J. A. Wyckoff, and R. A. Zinn. 1998. Influence of processed corn grain in diets of dairy cows on digestion of nutrients and milk composition. J. Dairy Sci. 81:2394-2407.

Cummings, J. H., D. A. T. Southgate, W. J. Branch, H. S. Wiggins, H. Houston, D. J. A. Jenkins, T. Jivraj, and M. J. Hill. 1979. The digestion of pectin in the human gut and its effect on calcium absorption and large bowel function. Br. J. Nutr. 41:477-485.

de Boer, I. J. M., M. C. J. Smits, H. Mollenhorst, G. van Duinkerken, and G. J. Monteny. 2002. Prediction of ammonia emission from dairy barns using feed characteristics. Part 1: Relation between feed characteristics and urinary urea concentration. J. Dairy Sci. 85:3382-3388.

Engelhardt, W., and G. Rechkemmer. 1983. The physiological effects of short-chain fatty acids in the hind gut. Pages 149-155 in Fibre in Human and Animal Nutrition. G. Wallace and L. Bell, ed. The Royal Society of New Zealand, Palmerston North, New Zealand.

Faichney, G. J. 1969. Production of volatile fatty acids in the sheep cecum. Aust. J. Agric. Res. 20:491-498.

Firkins, J. L. 1997. Effects of feeding nonforage fiber sources on site of fiber digestion. J. Dairy Sci. 80:1426-1437.

Fleming, S. E., D. Marthinsen, and H. Kuhnlein. 1983. Colonic function and fermentation in men consuming high fiber diets. J. Nutr. 113:2535-2544. 
Forsberg, C. W., K. J. Cheng, and B. A. White. 1997. Polysaccharide digestion in the rumen and large intestine. Pages 319-379 in Gastrointestinal Microbiology. R. I. Mackie and B. A. White, ed. Chapman and Hall, New York, NY.

Goering, H. K., and P. J. Van Soest. 1970. Forage Fiber Analyses. (Apparatus, Reagents, Procedures, and Some Applications). Agric. Handbook No. 379. ARS-USDA, Washington, DC.

Griinari, J. M., D. A. Dwyer, M. A. McGuire, D. E. Bauman, D. L. Palmquist, and K. V. V. Nurmela. 1998. Trans-octadecenoic acids and milk fat depression in lactating dairy cows. J. Dairy Sci. 81:1251-1261.

Hall, M. B., W. H. Hoover, J. P. Jennings, and T. K. M. Webster. 1999. A method for partitioning neutral detergent-soluble carbohydrates. J. Sci. Food Agric. 79:2079-2086.

Hatfield, R. D., and P. J. Weimer. 1995. Degradation characteristics of isolated and in situ cell wall lucerne pectic polysaccharides by mixed ruminal microbes. J. Sci. Food Agric. 69:185-196.

Hoover, W. H. 1978. Digestion and absorption in the hindgut of ruminants. J. Anim. Sci. 46:1789-1799.

Hristov, A. N., and J. K. Ropp. 2003. Effect of dietary carbohydrate composition and availability on utilization of ruminal ammonia nitrogen for milk protein synthesis in dairy cows. J. Dairy Sci. 86:2416-2427.

James, T., D. Meyer, E. Esparza, E. J. DePeters, and H. Perez-Monti. 1999. Effects of dietary nitrogen manipulation on ammonia volatilization from manure from Holstein heifers. J. Dairy Sci. 82:2430-2439.

Knowlton, K. F., B. P. Glenn, and R. A. Erdman. 1998. Performance, ruminal fermentation, and site of starch digestion in early lactation cows fed corn grain harvested and processed differently. J. Dairy Sci. 81:1972-1984.

Mason, V. C., P. Kessank, J. C. Ononiwu, and M. P. Narang. 1981 Factors influencing faecal nitrogen excretion in sheep. 2. Carbohydrate fermentation in the caecum and large intestine. Z. Tierphysiol. Tierernähr. Futtermittelkd. 45:174-184.

Myers, L. L., H. D. Jackson, and L. V. Packett. 1967. Absorption of volatile fatty acids from the cecum of sheep. J. Anim. Sci. 26:1450-1458.

National Research Council. 2001. Nutrient Requirements of Dairy Cattle. 7th rev. ed. Natl. Acad. Sci., Washington, DC.

Nocek, J. E., and J. B. Russell. 1988. Protein and energy as an integrated system. Relationship of ruminal protein and carbohydrate availability to microbial synthesis and milk production. J. Dairy Sci. 71:2070-2107.

Obispo, N. E., and B. A. Dehority. 1999. Feasibility of using total purines as a marker for ruminal bacteria. J. Anim. Sci. 77:3084-3095.

Ørskov, E. R., C. Fraser, V. C. Mason, and S. O. Mann. 1970. Influence of starch digestion in the large intestine of sheep on caecal fermentation, caecal microflora and faecal nitrogen excretion. Br. J. Nutr. $24: 671-682$

Pastuszewska, B., J. Kowalczyk, and A. Ochtabi?ska. 2000. Dietary carbohydrates affect caecal fermentation and modify nitrogen excretion patterns in rats. 1 . Studies with protein-free diets. Arch. Anim. Nutr. 53:207-225.

Pereira, M. N., and L. E. Armentano. 2000. Partial replacement of forage with nonforage fiber sources in lactating cow diets. II. Digestion and rumen function. J. Dairy Sci. 83:2876-2887.

Plascencia, A., and R. A. Zinn. 1996. Influence of flake density on the feeding value of steam-processed corn in diets for lactating cows. J. Anim. Sci. 74:310-316.
Rémésy, C., and C. Demigné. 1989. Specific effects of fermentable carbohydrates on blood urea flux and ammonia absorption in the rat cecum. J. Nutr. 119:560-565.

Reynal, S. M., G. A. Broderick, S. Ahvenjärvi, and P. Huhtanen. 2003. Effect of feeding protein supplements of differing degradability on omasal flow of microbial and undegraded protein. J. Dairy Sci. 86:1292-1305.

Reynal, S. M., G. A. Broderick, and C. Bearzi. 2005. Comparison of $15 \mathrm{~N}$, total purines, AA profiles, and urinary excretion of purine derivatives as markers for quantifying microbial protein flow from the rumen of lactating dairy cows. J. Dairy Sci. 88:4065-4082.

Reynolds, C. K., S. B. Cammell, D. J. Humphries, D. E. Beever, J. D. Sutton, and J. R. Newbold. 2001. Effects of postrumen starch infusion on milk production and energy metabolism in dairy cows. J. Dairy Sci. 84:2250-2259.

Rodríguez, C. A., J. González, M. R. Alvir, J. L. Repetto, C. Centeno, and F. Lamrani. 2000. Composition of bacteria harvested from the liquid and solid fractions of the rumen of sheep as influenced by feed intake. Br. J. Nutr. 84:369-376.

SAS Institute. 1999. SAS OnlineDoc.Version 8. SAS Institute, Inc. Cary, NC.

Satter, L. D., and R. E. Roffler. 1975. Nitrogen requirement and utilization in dairy cattle. J. Dairy Sci. 58:1219-1237.

Souffrant, W. B. 2001. Effect of dietary fibre on ileal digestibility and endogenous nitrogen losses in the pig. Anim. Feed Sci. Technol. 90:93-102.

Sukhija, P. S., and D. L. Palmquist. 1988. Rapid method for determination of total fatty acid content and composition of feedstuffs and feces. J. Agric. Food Chem. 36:1202-1206.

Sunvold, G. D., H. S. Hussein, G. C. Fahey, Jr., N. R. Merchen, and G. A. Reinhart. 1995. In vitro fermentation of cellulose, beet pulp, citrus pulp, and citrus pectin using fecal inoculum from cats, dogs, horses, humans, and pigs and ruminal fluid from cattle. J. Anim. Sci. 73:3639-3648

Surra, J. C., J. A. Guada, J. Balcells, and C. Castrillo. 1997. Effects of post-ruminal fermentation on the faecal and urinary excretion of purines. Anim. Sci. 65:383-390.

Thornton, R. F., P. R. Bird, M. Somers, and R. J. Moir. 1970. Urea excretion in ruminants. III. The role of the hind-gut (caecum and colon). Aust. J. Agric. Res. 21:345-354.

Vagnoni, D. B., and G. A. Broderick. 1997. Effects of supplementation of energy or ruminally undegraded protein to lactating cows fed alfalfa hay or silage. J. Dairy Sci. 80:1703-1712.

Van Soest, P. J., J. B. Robertson, and B. A. Lewis. 1991. Methods for dietary fiber, neutral detergent fiber, and nonstarch polysaccharides in relation to animal nutrition. J. Dairy Sci. 77:35833597

Varel, V. H., J. A. Nienaber, and H. C. Freetly. 1999. Conservation of nitrogen in cattle feedlot waste with urease inhibitors. J. Anim. Sci. 77:1162-1168

Vicente, F., J. A. Guada, J. Surra, J. Balcells, and C. Castrillo. 2004. Microbial contribution to duodenal purine flow in fattening cattle given concentrate diets, estimated by purine N labeling $(15 \mathrm{~N})$ of different microbial fractions. Anim. Sci. 78:159-167.

Wattiaux, M. A., and K. L. Karg. 2004. Protein level for alfalfa and corn silage-based diets: II. Nitrogen balance and manure characteristics. J. Dairy Sci. 87:3492-3502.

Wright, T. C., S. Moscardini, P. H. Luimes, P. Susmel, and B. W. McBride. 1998. Effects of rumen-undegradable protein and feed intake on nitrogen balance and milk protein production in dairy cows. J. Dairy Sci. 81:784-793.

Younker, R. S., S. D. Winland, J. L. Firkins, and B. L. Hull. 1998. Effects of replacing forage fiber or nonfiber carbohydrates with dried brewers grains. J. Dairy Sci. 81:2645-2656. 